\title{
UICN
}

\section{Integração da perspectiva da mudança climática na restauração da Bacia do Rio Doce}

P. May, L. Alonso, F.A.R. Barbosa, M.C.W. Brito,

F.V. Laureano, C. Maroun, L.E. Sánchez, Y. Kakabadse

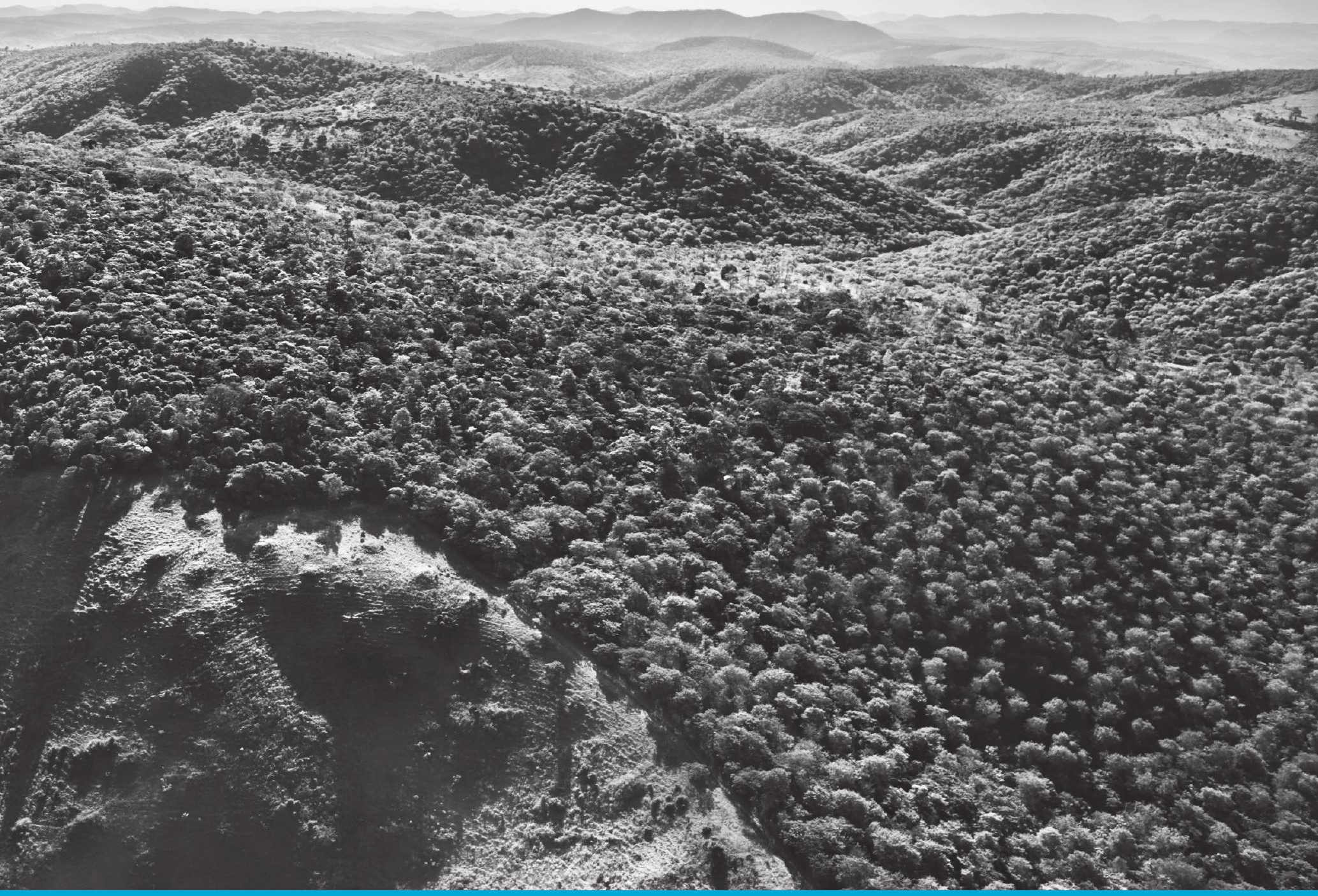

RELATÓRIO TEMÁTICO № 2 DO PAINEL DO RIO DOCE 


\section{Sobre a UICN}

A UICN é uma união de membros composta exclusivamente por organizações governamentais e da sociedade civil. Ela fornece às organizações públicas, privadas e não-governamentais uma série de conhecimentos e ferramentas que possibilitam que o progresso humano, o desenvolvimento econômico e a conservação da natureza ocorram juntos.

Criada em 1948, a UICN é hoje a maior e mais diversificada rede ambiental do planeta, reunindo os conhecimentos, os recursos e o alcance de mais de 1.400 organizações membros e cerca de 15.000 especialistas. A UICN é líder na produção de dados, avaliações e análises sobre conservação. Com um amplo quadro de membros, a UICN assume o papel de incubadora e de repositório confiável de melhores práticas, ferramentas e padrões internacionais.

A UICN oferece um espaço neutro para as diversas partes interessadas - incluindo governos, ONGs, cientistas, empresas, comunidades locais, organizações de povos indígenas e outros - trabalharem juntas para conceber e implementar soluções para os desafios ambientais e alcançar o desenvolvimento sustentável.

www.iucn.org

https://twitter.com/IUCN/ 


\section{Integração da perspectiva da mudança climática na restauração da Bacia do Rio Doce \\ P. May, L. Alonso, F.A.R. Barbosa, M.C.W. Brito, \\ F.V. Laureano, C. Maroun, L.E. Sánchez, Y. Kakabadse}


A designação de entidades geográficas neste livro e a apresentação do material não implicam a expressão de qualquer opinião por parte da UICN sobre a situação legal de qualquer país, território ou área, ou de suas autoridades, ou no que concerne à delimitação de suas fronteiras ou limites.

As opiniões expressas nesta publicação não refletem, necessariamente, as opiniões da UICN.

A UICN agradece o apoio de seus Parceiros Estruturais responsáveis pelo financiamento principal: o Ministério das Relações Exteriores da Finlândia; o Governo da França e a Agência Francesa de Desenvolvimento (AFD); o Ministério do Meio Ambiente da República da Coreia; a Agência Norueguesa de Cooperação para o Desenvolvimento (Norad); a Agência Sueca de Cooperação Internacional para o Desenvolvimento (Sida); a Agência Suíça para o Desenvolvimento e Cooperação (SDC) e o Departamento de Estado dos Estados Unidos.

O contexto econômico, ambiental e social da bacia do Rio Doce é dinâmico e está em constante mudança. O Painel do Rio Doce preparou este estudo com a melhor informação de acesso público disponível no momento de sua redação, e reconhece que novos estudos estão em andamento e contriburão para esclarecer as informações sobre os esforços de restauração.

A UICN não se responsabiliza por erros ou omissões que possam ocorrer na tradução para o português deste documento, cuja versão original é em inglês. Em caso de discrepâncias, consulte a edição original. Título da edição original: Mainstreaming climate change in the Rio Doce watershed restoration. Rio Doce Panel Thematic Report No. 2. (2020). Gland, Switzerland: IUCN. DOI: https://doi.org/10.2305/IUCN.CH.2020.06.en

Publicado por: $\quad$ UICN, Gland, Suíça

Direito autoral: @ @ 2020 UICN, União Internacional para a Conservação da Natureza e Recursos Naturais

A reprodução desta publicação para fins educacionais ou outros fins não comerciais é permitida sem autorização prévia por escrito do titular dos direitos autorais, desde que a fonte seja plenamente reconhecida.

É proibida a reprodução desta publicação para revenda ou outros fins comerciais sem autorização prévia por escrito do titular dos direitos autorais.

Citação: $\quad$ May, P. Alonso, L., Barbosa, F.A.R., Brito, M.C.W., Laureano, F.V., Maroun, C., Sánchez, L.E., Kakabadse, Y. (2020). Integração da perspectiva da mudança climática na restauração da Bacia do Rio Doce. Relatório Temático nº 2 do Painel do Rio Doce. Gland, Suíça: UICN.

ISBN:

978-2-8317-2050-0 (PDF)

978-2-8317-2065-4 (print)

DOI:

https://doi.org/10.2305/IUCN.CH.2020.06.pt

Tradução: $\quad$ Leonardo Padovani

Revisão: $\quad$ Ana Terra

Foto da capa: Vista do entorno da Reserva Particular do Patrimônio Natural (RPPN) Fazenda Bulcão, o contraste com áreas desmatadas. Foto: Sebastião Salgado. Cortesia do Instituto Terra.

Edição e layout: Diwata Hunziker

Disponível em: UICN (União Internacional para a Conservação da Natureza)

Programa Global de Negócios e Biodiversidade

Rue Mauverney 28

1196 Gland

Suíça

www.iucn.org/pt/paineldoriodoce

www.iucn.org/resources/publications 


\section{Sumário}

Lista de figuras e quadros iv

Lista de abreviaturas e siglas iv

Agradecimentos v v

Apresentação vi vi vina vis

Prefácio vii

Sumário executivo viii

1 Introdução 1

2 Avaliação da vulnerabilidade da bacia hidrográfica do Rio Doce 4

2.1 Condições climáticas no Rio Doce 4

2.2 Projeções de modelagem climática na Bacia do Rio Doce 5

2.3 Potencial impacto da mudança climática nas pessoas e no meio 9 ambiente da Bacia do Rio Doce

3 Riscos e oportunidades: passos em direção à ação climática 12

3.1 Possibilidades de ação 12

3.2 Adaptação à mudança climática nos programas do TTAC 12

3.3 Oportunidades de sequestro de carbono em sistemas naturais $\quad 18$

3.4 Estratégias para eficiência energética, uso e geração 19 de energia

4 Caminhos alternativos 22

4.1 Modalidades de financiamento para a ação climática 22

4.2 Soluções baseadas na Natureza para a adaptação climática 23

5 Conclusões e recomendações 25

$\begin{array}{ll}\text { Referências } & 30\end{array}$

Anexo: definição de termos selecionados $\quad 35$ 


\section{Lista de figuras e quadros}

\section{Lista de siglas}

Figura 1 Região da bacia hidrográfica do Rio Doce e limites estaduais

Figura 2 Classificação climática da Bacia do Rio Doce

Figura 3 Variações de temperatura (a) e precipitação (b) projetadas para 2080 na parte mineira da bacia hidrográfica do Rio Doce nos cenários A2-BR e B2-BR

Figura 4 Cenários de mudança climática no Espírito Santo de 1982 a 2011 e em 2050: precipitação média anual (a) e temperatura média anual (b)

Quadro 1 Exposição a impactos da mudança climática na região da Bacia do Rio Doce em Minas Gerais

Quadro 2 Programas do TTAC vulneráveis aos impactos da mudança climática

Quadro 3 Oportunidades de promover ou aumentar a eficiência energética e o uso de energia renovável em programas do TTAC
5

6

CND

$\mathrm{CO}_{2} \mathrm{eq}$

COP

8

CT-Flor

EE

ER

FEAM-MG

11

\section{Gaisma}

GEE

Ibama

9

ICMBio

INPE

ISTAP

14

21

PIB

PSA

$\mathrm{SbN}$

Seama-ES

Semad-MG Secretaria de Estado de Meio Ambiente e Desenvolvimento Sustentável de Minas Gerais

SIRENE Sistema de Registro Nacional de Emissões

TTAC Termo de Transação e de Ajustamento de Conduta

UHE Usina hidrelétrica

UICN União Internacional para a Conservação da Natureza

UNFCCC United Nations Framework Convention on Climate Change (Convenção-Quadro das Nações Unidas sobre a Mudança do Clima) 


\section{Agradecimentos}

O Painel do Rio Doce agradece às seguintes pessoas que contribuíram com informações importantes e opiniões sobre os programas de mitigação e compensação:

- Representantes dos governos subnacionais envolvidos, principalmente dos estados de Minas Gerais e Espírito Santo e dos municípios afetados pelo rompimento da Barragem de Fundão;

- Representantes de órgãos ambientais de governo, a saber: Secretaria de Estado de Meio Ambiente e Recursos Hídricos do Espírito Santo (Seama-ES), Secretaria de Estado de Meio Ambiente e Desenvolvimento Sustentável de Minas Gerais (Semad-MG), Fundação Estadual do Meio Ambiente de Minas Gerais (FEAMMG), Instituto Chico Mendes de Conservação da Biodiversidade (ICMBio) e Instituto Brasileiro do Meio Ambiente e dos Recursos Naturais Renováveis (lbama);

- Representantes de organizações não governamentais locais; e

- Membros da UICN (União Internacional para a Conservação da Natureza) no Brasil que contribuíram para o trabalho do Painel.

Este relatório não teria sido possível sem o apoio e feedback da Fundação Renova e de suas equipes técnicas envolvidas na implementação dos programas do Termo de Transação e de Ajustamento de Conduta (TTAC). Também agradecemos aos dois revisores externos e anônimos, cujo trabalho foi essencial para a elaboração deste relatório.

O Painel também agradece ao Instituto Terra, à Prefeitura Municipal de Governador Valadares e à equipe de comunicação da Fundação Renova, por ceder os direitos de uso das imagens utilizadas no Relatório e em outros materiais de comunicação, bem como pela prontidão no atendimento aos pedidos da equipe.

Finalmente, agradecemos à equipe da UICN pelo apoio técnico contínuo ao Painel e, em particular, pelo trabalho árduo na produção deste relatório, especialmente Caroline Cogueto, Fabio Junior, Fernanda Maschietto, Florian Reinhard, Leigh Ann Hurt, Renata Bennet e Stephen Edwards. 


\section{Apresentação}

Ecossistemas e recursos naturais saudáveis sustentam os meios de vida e a economia global. Hoje, no entanto, a emergência climática representa uma ameaça crescente à saúde humana e à saúde dos ecossistemas. A previsão é de que doenças emergentes, racionamentos de água, secas e inundações ocorram com mais frequência nos próximos anos, evidenciando a necessidade de mudanças sociais para mitigar esses desafios iminentes. Em paisagens degradadas como a Bacia do Rio Doce - que ainda se recupera do rompimento da Barragem de Fundão em 2015 - a expectativa é de que a mudança climática agrave uma paisagem que já era frágil. Por exemplo, as chuvas torrenciais na região que ocorreram no primeiro semestre de 2020 causaram deslizamentos de terra severos, deixando centenas de pessoas desabrigadas e potencialmente trazendo à tona sedimentos que podem expor as pessoas e o meio ambiente aos efeitos nocivos causados pelo rompimento da barragem cinco anos atrás.

Neste importante e oportuno relatório, o Painel independente do Rio Doce chama a atenção para a necessidade de os tomadores de decisão considerarem os impactos climáticos nos esforços de restauração desta importante bacia, agora e no futuro. Visto que cerca de 3,3 milhões de pessoas dependem do Rio Doce para acesso à água doce e garantia de sua subsistência, são necessárias medidas urgentes para ajudar as comunidades a mitigar e se adaptar aos impactos da mudança climática. A prevenção desses impactos está alinhada com a agenda global da Década da ONU para a Restauração dos Ecossistemas, cujo objetivo será prevenir, interromper e reverter a destruição de ecossistemas danificados.

As questões tratadas nesta publicação refletem os desafios e soluções globais para o enfrentamento da mudança climática. As conclusões científicas mais recentes publicadas pelo Painel Intergovernamental sobre Mudanças Climáticas ressaltam a gravidade da ameaça que a mudança climática representa para os sistemas naturais e humanos em todo o planeta, e sabemos que precisamos agir imediatamente para reduzir as emissões de gases de efeito estufa. Felizmente, as Soluções baseadas na Natureza e outras ações de mitigação com base no ecossistema são maneiras eficientes, econômicas e comprovadas de responder aos desafios impostos pela mudança climática, além de apresentarem oportunidades de conservação, restauração e gestão sustentável de bacias hidrográficas importantes como a do Rio Doce.

De acordo com o relatório do Painel, esforços municipais e estaduais são fundamentais para fortalecer a capacidade de adaptação e deixar as regiões e comunidades vulneráveis mais resilientes à mudança climática. Tais esforços incluem a restauração das funções do ecossistema - por exemplo, a plantação de árvores nativas ao longo dos rios e nas encostas e a identificação do potencial dos programas de restauração de reduzirem o nível de emissões. A Bacia do Rio Doce precisa de mais políticas e investimentos prospectivos para fortalecer a saúde e aumentar o bem-estar de longo prazo das pessoas e do meio ambiente. A UICN aprecia este relatório oportuno, que fornece orientações inestimáveis para enfrentar os desafios climáticos na região e além.

Dra. Grethel Aguilar

Diretora-Geral Interina

UICN, União Internacional para a Conservação da Natureza 


\title{
Prefácio
}

Criado em 2017 sob a liderança da União Internacional para a Conservação da Natureza (UICN), o Painel do Rio Doce continua a assessorar a restauração da Bacia do Rio Doce, no Brasil, afetada pelo rompimento da Barragem de Fundão em 2015. Visando trazer uma perspectiva de longo prazo para essa bacia hidrográfica de tamanha importância, o Painel assessora os esforços de recuperação da Fundação Renova e de partes interessadas para construir um ecossistema mais sustentável e resiliente na bacia e na zona costeira adjacente.

Em seu primeiro relatório, Os impactos do rompimento da Barragem de Fundão: o caminho para uma mitigação sustentável e resiliente, o Painel identifica a mudança climática como a maior ameaça aos sistemas naturais, às comunidades locais e às empresas que atuam na bacia. O Painel insta a Fundação Renova, responsável por implementar os esforços de restauração e compensação, a incluir a perspectiva climática em suas ações.

O desastre de Fundão exacerbou a vulnerabilidade da região, que já se encontrava severamente degradada após décadas de atividades insustentáveis. O rompimento da barragem causou 19 mortes e sérios impactos à natureza, à saúde e aos meios de subsistência na região. A expectativa das comunidades afetadas é um ambiente natural e social restaurado e mais seguro; os tomadores de decisão, por sua vez, devem adotar medidas olhando para o futuro para garantir que as intervenções socioambientais já em andamento contribuam para uma sociedade mais sustentável e resiliente, com maior capacidade de conservar, usar e proteger a terra.

Com base nas recomendações anteriores do Painel do Rio Doce (descritas em seu primeiro relatório e em estudos da série "Questões em Foco"), o Painel conclui que a Fundação Renova deve priorizar as medidas de mitigação e adaptação climática no planejamento e na implementação de seus programas. O relatório identifica várias maneiras como a Fundação Renova pode melhorar seus esforços de forma permanente para aumentar a resiliência climática, como o uso de Soluções baseadas na Natureza e a manutenção da infraestrutura natural de água, além do fortalecimento da cooperação para aprimorar as capacidades institucionais.

Por fim, o Painel conclui que a ação climática é essencial para a construção de um legado positivo e duradouro para as gerações atual e futuras. O que segue é um convite para um diálogo sobre a recuperação da Bacia do Rio Doce a longo prazo.

\author{
Yolanda Kakabadse \\ Presidente \\ Painel do Rio Doce
}




\section{Sumário executivo}

A mudança climática prevista pode representar um risco para o legado dos programas de restauração empreendidos atualmente pela Fundação Renova na Bacia do Rio Doce. Neste relatório, o Painel do Rio Doce propõe que a Renova e as organizações de partes interessadas e tomadores de decisão que atuam na Bacia iniciem um plano de ação para tratar desses possíveis riscos.

O relatório contextualiza as condições climáticas na bacia hidrográfica do Rio Doce e as consequências de possíveis mudanças nos padrões atuais de temperatura e precipitação. $\mathrm{O}$ aumento do risco de mudança climática deixa as comunidades do Rio Doce mais vulneráveis a eventos como inundações, deslizamentos de terra e erosão costeira, indicando a necessidade de políticas e investimentos para gerar resiliência institucional e social para a adaptação à mudança climática, principalmente no que diz respeito à saúde humana e à saúde dos ecossistemas. Cientistas climáticos do Brasil afirmam que as chuvas intensas na região Sudeste em 2020 refletem mudanças de longo prazo influenciadas pelo aquecimento global. A adaptação à mudança climática impõe a necessidade de gerar capacidade institucional entre agências de governo e redes sociais de atores para responder a desafios futuros.

Existem vários programas transversais de restauração, implementados pela Fundação Renova, que aumentam a resiliência climática, mas é evidente a necessidade de uma maior coordenação entre os programas para garantir sua capacidade de adaptação. O relatório discute oportunidades de mitigação e redução das emissões, além do potencial de instrumentos financeiros capazes de gerar recursos para sua implementação (por exemplo, a precificação de carbono e fundos de investimento verde) ou facilitar sua adoção - por exemplo, sistemas de pagamento por serviços ambientais (PSA). O relatório também recomenda a adoção de Soluções baseadas na Natureza (SbN) em abordagens de paisagem para a adaptação e mitigação climáticas em toda a bacia, citando as ações exemplares da Renova de renaturalização de cursos d'água.

O Painel recomenda que a Renova busque soluções para as possíveis ameaças que a mudança climática representa para a eficácia e sustentabilidade de seus programas e, dessa forma, contribua para uma economia de baixo carbono e uma sociedade resiliente nessa bacia hidrográfica.

A Renova deve coordenar suas atividades transversais para aumentar a alavancagem e acumular uma base de evidências para uso em ações climáticas no futuro, além de trabalhar em cooperação com os governos locais e estaduais para fortalecer as capacidades institucionais de adaptação à mudança climática. Nesse sentido, o Painel recomenda que a Renova coopere com as partes interessadas e instituições parceiras, incluindo governos estaduais e locais, promotores públicos e o poder judiciário, para:

1) iniciar um diálogo em direção ao desenvolvimento de um Plano de Ação Climática para a Bacia do Rio Doce;

2) propor que o Comitê Interfederativo (CIF) e outras entidades integrem a perspectiva da mudança climática em uma revisão oportuna dos programas relevantes no âmbito do Termo de Transação e de Ajustamento de Conduta (TTAC) ${ }^{1}$;

3) adotar $\mathrm{SbN}$ ao considerar alternativas tecnológicas de remediação, restauração e compensação; e

4) convidar governos estaduais e locais a desenvolver suas capacidades e empreender ações preparatórias para se adaptarem à mudança climática.

1 Para mais informações, visite: www.samarco.com/en/plano-de-recuperacao-macro/

viii 


\section{1 | Introdução}

A mudança climática é um fenômeno global que afeta todas as formas de vida na Terra. A biodiversidade e os serviços ecossistêmicos do planeta - e, consequentemente, o bem-estar humano - sofrem efeitos diretos e indiretos. Embora as economias e os meios de subsistência do planeta dependam de recursos naturais e ecossistemas, prevê-se que esses ativos, bem como as infraestruturas construídas pelo homem, a saúde e a segurança alimentar, continuarão a ser afetados pela mudança climática. Ao mesmo tempo, um número cada vez maior de pesquisas científicas reconhece a influência das atividades humanas no aumento da concentração de gases de efeito estufa (GEE) na atmosfera, o que por sua vez afeta as tendências recentes de mudança climática em escala global. Mudanças nas chuvas, nos padrões de temperatura e na frequência de eventos extremos - como inundações, incêndios, secas, ciclones e furacões - são algumas das consequências da maior concentração de GEE na atmosfera (IPCC, 2014a).

Ainda é cedo para a publicação de verificações científicas, mas os climatologistas do Brasil afirmam que as chuvas intensas de 2020 na região Sudeste, acompanhadas de secas em outras partes do país, refletem mudanças de longo prazo nos padrões de chuvas atribuídas ao aquecimento global (Phillips, 2020). As consequências da mudança climática variam entre locais e grupos sociais. Não há dúvida de que as cidades são as mais vulneráveis ao aumento da intensidade das chuvas, já que não é possível adaptar, rapidamente, sua infraestrutura de drenagem de águas pluviais em resposta a eventos extremos. A população do Brasil está se tornando cada vez mais urbana; no bioma Mata Atlântica, a população urbana é ainda mais densa. Ao mesmo tempo, os impactos da mudança climática não poupam as áreas rurais. A agricultura e a silvicultura estão entre os setores mais afetados pela seca e pelo aumento da temperatura; já o turismo costeiro pode ser impactado pela elevação do nível do mar e pela erosão (Margulis, 2017). As estratégias de adaptação são indispensáveis.

O rompimento da Barragem de Fundão deixou clara a necessidade de adaptação para responder às perdas materiais e ao sofrimento humano, pois contribuiu para o aumento da vulnerabilidade da região devido, entre outras consequências, à interrupção de atividades econômicas que sustentam os meios locais de subsistência; ao estresse psicológico ocasionado pela perda de estruturas e equipamentos comunitários que faziam parte da cultura da região; e a impactos ambientais. A Fundação Renova foi criada para responder a esse grande desastre, envidando esforços para mitigar e compensar seus impactos socioeconômicos e ambientais. Trabalhando sob condições rigorosas de governança, a fundação é responsável pela implementação de 42 programas ambientais e socioeconômicos delineados em um acordo extrajudicial denominado Termo de Transação e de Ajustamento de Conduta (TTAC). O acordo também levou à criação de um Comitê Interfederativo (CIF), composto por representantes de órgãos de governos das esferas municipal, estadual e federal, comitês de bacia e, mais recentemente, representantes das populações afetadas, para monitorar os avanços e resultados dos programas. A experiência acumulada pela Renova em lidar de forma interdisciplinar com um conjunto de tarefas complexas em uma estrutura de governança multinível serve como parte do legado dos programas para a Bacia do Rio Doce e suas populações.

Em consonância com sua missão, o Painel do Rio Doce ressalta a necessidade de incluir respostas à mudança climática nos programas de mitigação e 
Adaptação à mudança climática e a redução de emissões são essenciais para a sustentabilidade e resiliência dos resultados dos programas do TTAC

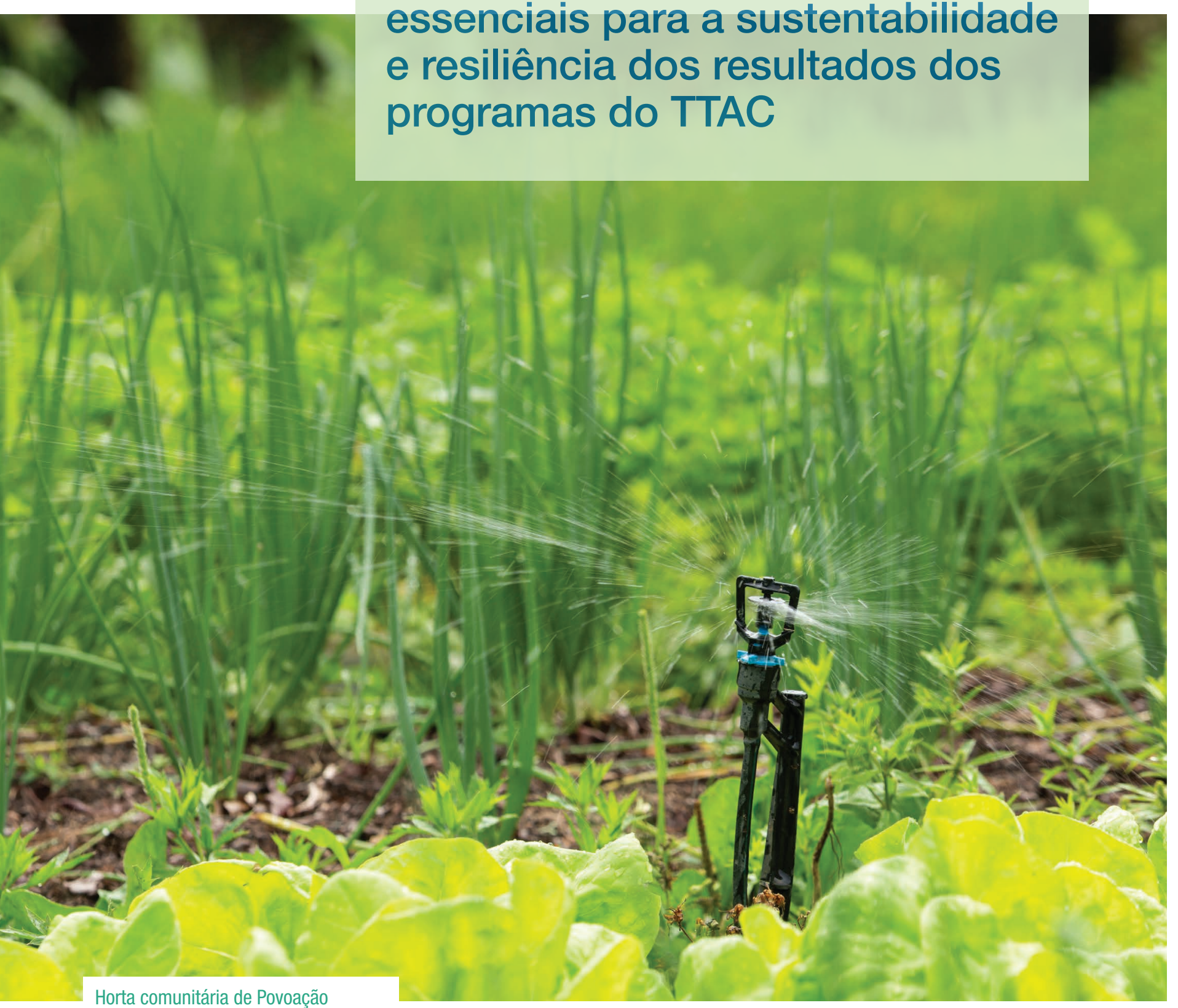

Foto: NITRO (outubro 2018). 
compensação descritos no TTAC. ${ }^{2}$ Portanto, em seu primeiro relatório temático, o Painel recomendou que Renova e CIF revisem os programas do TTAC para avaliar os possíveis impactos da mudança climática sobre os resultados pretendidos e adaptar ou modificar os programas para refletir a principal preocupação do Painel: os esforços de mitigação e compensação devem resultar num legado positivo e duradouro para as gerações atual e futuras (Sánchez et al., 2018).

Este segundo relatório temático trata da necessidade de incluir respostas adequadas à mudança climática nos esforços de mitigação e compensação em andamento na bacia hidrográfica do Rio Doce, associadas à adaptação à mudança climática e à redução de emissões, essenciais para a sustentabilidade e resiliência dos resultados dos programas do TTAC.
O relatório está organizado em cinco seções.

A seção 1 apresenta o escopo do relatório e sua relação com os programas do TTAC implementados pela Renova após o rompimento da Barragem de Fundão. A seção 2 apresenta um quadro de mudança climática na bacia hidrográfica do Rio Doce, bem como sua vulnerabilidade aos impactos derivados e riscos associados. A seção 3 analisa até que ponto a mudança climática pode afetar os resultados de longo prazo pretendidos pelos programas do TTAC e avalia como usos alternativos da terra e alternativas energéticas podem contribuir para a redução das emissões de GEE. A seção 4 propõe algumas opções para o financiamento de iniciativas de baixo carbono assim como para a adoção de SbN. Por fim, a seção 5 traz recomendações para a Renova e as instituições parceiras visando melhorar o processo decisório relativo à integração de iniciativas de baixo carbono e aumentar a resiliência dos programas de mitigação e compensação da Renova à luz das mudanças globais que vêm ocorrendo. Uma definição de termos selecionados está disponível no Anexo.

2 O Painel do Rio Doce foi criado em 2017 como um Painel Independente de Assessoria Técnica e Científica (ISTAP, do inglês Independent Scientific Technical Advisory Panel), coordenado pela União Internacional para a Conservação da Natureza (UICN). O objetivo geral do Painel é assessorar a Fundação Renova, de forma objetiva e independente, na recuperação da Bacia do Rio Doce após o rompimento da Barragem de Fundão, em novembro de 2015. Para mais informações, consulte: https://www. iucn.org/pt/paineldoriodoce 


\section{2 | Avaliação da vulnerabilidade da bacia hidrográfica do Rio Doce}

No contexto da mudança climática, a vulnerabilidade pode ser definida como "o grau em que um sistema é suscetível a - e incapaz de lidar com - os efeitos adversos das alterações climáticas, incluindo variabilidade do clima e extremos climáticos" (IPCC, 2007a, p. 883). De modo geral, as pessoas mais vulneráveis são aquelas criticamente expostas a fontes duradouras de estresse socioambiental.

Em 2011, a Fundação Estadual do Meio Ambiente de Minas Gerais (FEAM-MG) realizou uma avaliação da mudança climática prevista no Estado de Minas Gerais incluindo a parte mineira da Bacia do Rio Doce, concluindo que mudanças significativas são esperadas nas próximas décadas. ${ }^{3}$ Com essas alterações, aumenta a vulnerabilidade da bacia hidrográfica do Rio Doce e de suas populações.

Além da ameaça representada pela mudança climática, o rompimento da Barragem de Fundão um evento de grande escala e alto impacto e com repercussões de longo prazo - exacerbou a situação de vulnerabilidade em que a bacia hidrográfica do Rio Doce e a zona costeira adjacente já se encontravam. Embora alguns dos efeitos imediatos mais críticos - por exemplo, as proibições de pesca, as demissões de trabalhadores e a realocação das famílias - tenham sido compensados parcialmente por pagamentos às partes afetadas, é difícil atribuir um nexo causal a efeitos menos tangíveis, como os que recaem sobre a saúde humana e do ecossistema. Além disso, foi reportado que chuvas fortes deslocaram sedimentos depositados ao longo do rio (Queiroz et al., 2018) e podem ter ressuspendido rejeitos depositados pelo rompimento da barragem, indicando que a intensificação de eventos associados à mudança climática pode continuar afetando as condições da bacia. Nessas circunstâncias, é importante garantir que os programas do TTAC, bem como os investimentos complementares do governo, sejam resilientes e adaptados aos possíveis impactos da mudança climática.

Esta seção descreve a bacia sob uma perspectiva climatológica, identificando através de projeções locais e globais as mudanças de temperatura e precipitação previstas nas próximas décadas. Da mesma forma, os fatores ambientais e socioeconômicos que provavelmente serão afetados por essas mudanças na bacia hidrográfica do Rio Doce são apresentados para fundamentar uma análise preliminar dos programas do TTAC e seu potencial de contribuir para a resiliência da região à mudança climática.

\subsection{Condições climáticas no Rio Doce}

A bacia hidrográfica do Rio Doce (Figura 1) compreende aproximadamente $86.715 \mathrm{~km}^{2}$. Em Minas Gerais se localizam $86 \%$ da bacia hidrográfica; os 14\% restantes ficam no Espírito Santo. ${ }^{4}$ A cabeceira do rio fica em Minas Gerais, nas serras da Mantiqueira e do Espinhaço, e suas águas fluem por aproximadamente $850 \mathrm{~km}$ até chegar ao Oceano Atlântico, na cidade de Regência (Espírito Santo). ${ }^{5}$

O regime pluviométrico da Bacia do Rio Doce é caracterizado por dois períodos muito distintos. O período chuvoso, quando a precipitação total varia de 800 a 1.300 mm, se estende de outubro a março, com as maiores taxas em dezembro. O período seco, quando a precipitação total varia de 150 a 250 mm, vai de abril a setembro, com o déficit mais crítico de junho a agosto.

3 Detalhes sobre os resultados da avaliação da FEAM serão abordados nas seções 2.2 e 2.3.

4 Para mais informações, ver: http://www3.ana.gov.br/portal/ANA/panorama-das-aguas/divisoes-hidrograficas.

5 Para mais informações, consulte o site da Agência Nacional de Águas: https://www.ana.gov.br/sala-de-situacao/rio-doce/riodoce-saiba-mais 


\section{Figura1}

Região da bacia hidrográfica do Rio Doce e limites estaduais

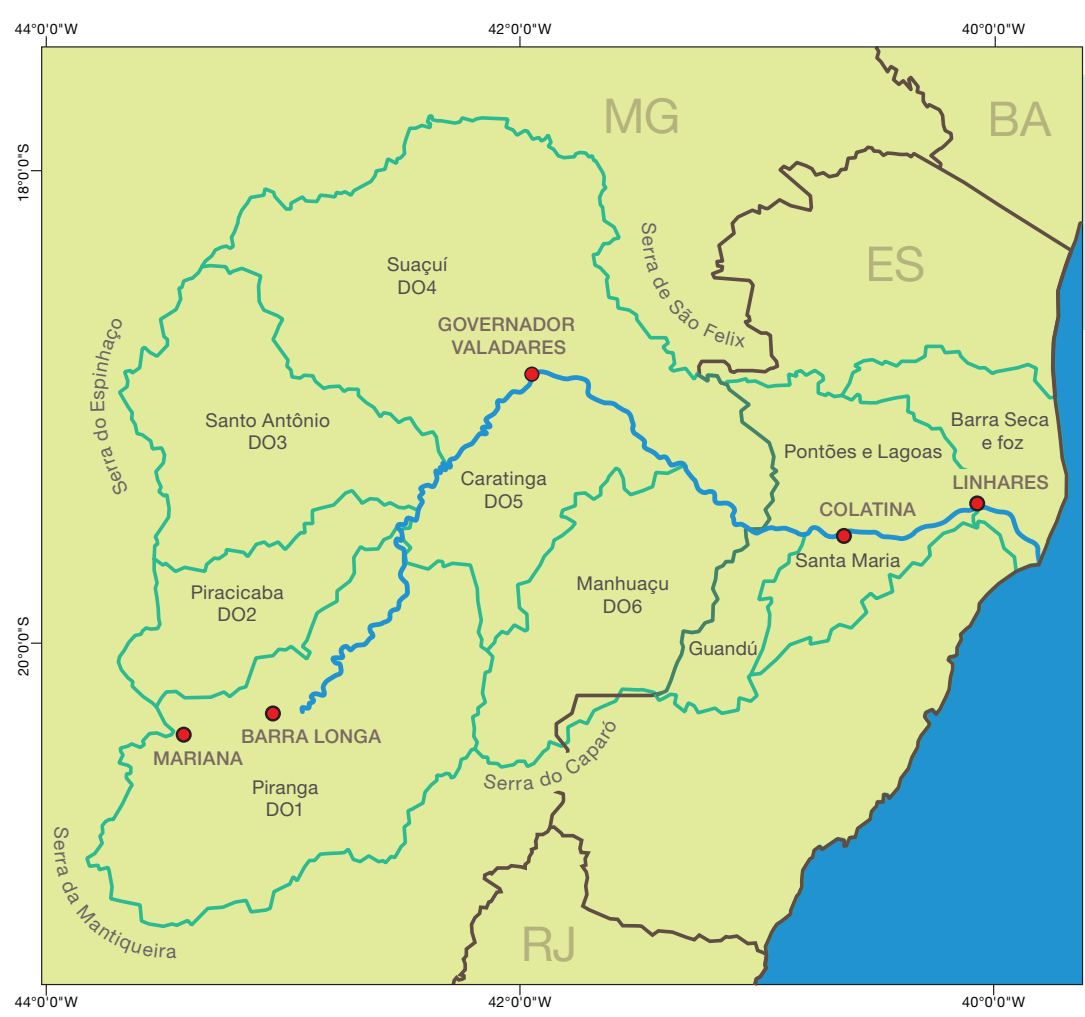

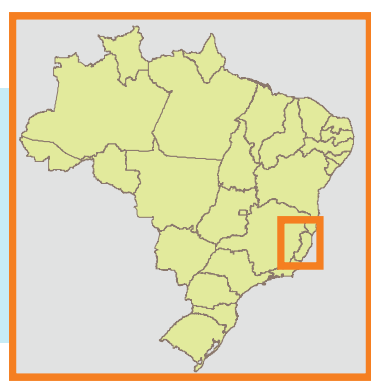

Sedes Municipais

Rio Doce

- Unidades Hidrográficas Administrativas

- Limite Estadual

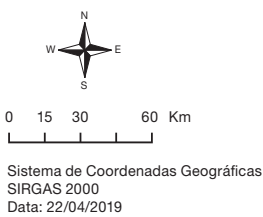

Fonte: Fundação Renova.

Cupolillo et al. (2008) identificaram um padrão de precipitação oeste-leste: na parte oeste da bacia, a estação chuvosa é mais longa, e a estação seca, mais curta. Na parte leste, acontece o oposto: a estação chuvosa é mais curta, e a estação seca, mais longa. Também ocorrem veranicos (períodos de seca durante a estação chuvosa) por toda a bacia. Estes são mais intensos perto do litoral, onde costumam durar 10 dias em fevereiro.

De acordo com a Agência Nacional de Águas (ANA), a bacia é suscetível a inundações, principalmente em áreas urbanas ao longo do curso do Rio Doce e em alguns de seus afluentes. Essas inundações são registradas na estação chuvosa, em especial de dezembro a fevereiro.

Esse é o cenário no qual os efeitos da mudança climática podem ocorrer, com níveis variados de impacto determinados pela dependência relativa das atividades econômicas e dos assentamentos humanos na estabilidade dos regimes de temperatura e precipitação.

\subsection{Projeções de modelagem climática na Bacia do Rio Doce}

Houve grandes avanços nas últimas décadas na compreensão e previsão das condições climáticas e dos fenômenos atmosféricos a longo prazo, principalmente por parte do Painel Intergovernamental de Mudanças Climáticas (IPCC, 2007b; 2014a; 2018a). Hoje, as previsões e projeções são produtos de modelos climáticos numéricos desenvolvidos em supercomputadores. No campo da modelagem climática, o uso contínuo de uma abordagem científica robusta e de novas tecnologias - por exemplo, a inteligência artificial (Voosen, 2018) - reduziu consideravelmente as incertezas. No entanto, a implementação de acordos de política climática tem o potencial de reduzir o forçamento antropogênico nos processos que 
levam à mudança climática. Assim, as expectativas de adoção de políticas climáticas também são incorporadas nos modelos, resultando em cenários que refletem condições de aquecimento global mais ou menos intensas. ${ }^{6}$

Em sintonia com os esforços globais para entender os impactos da mudança climática e os desafios da adaptação a seus efeitos, o Instituto Nacional de Pesquisas Espaciais (INPE) tem reduzido periodicamente a escala dos modelos globais para enfocar a América do Sul, toda ou em parte. ${ }^{7}$ De acordo com José Marengo, renomado climatologista do INPE, a modelagem de cenários climáticos futuros no Brasil apresenta forte consenso pelo aumento da temperatura neste século (Piveta, 2018). De forma consistente, os modelos preveem anomalias positivas de temperatura entre $2^{\circ} \mathrm{C} \mathrm{e} 4^{\circ} \mathrm{C}$ acima da média atual

Figura 2

Classificação climática da Bacia do Rio Doce

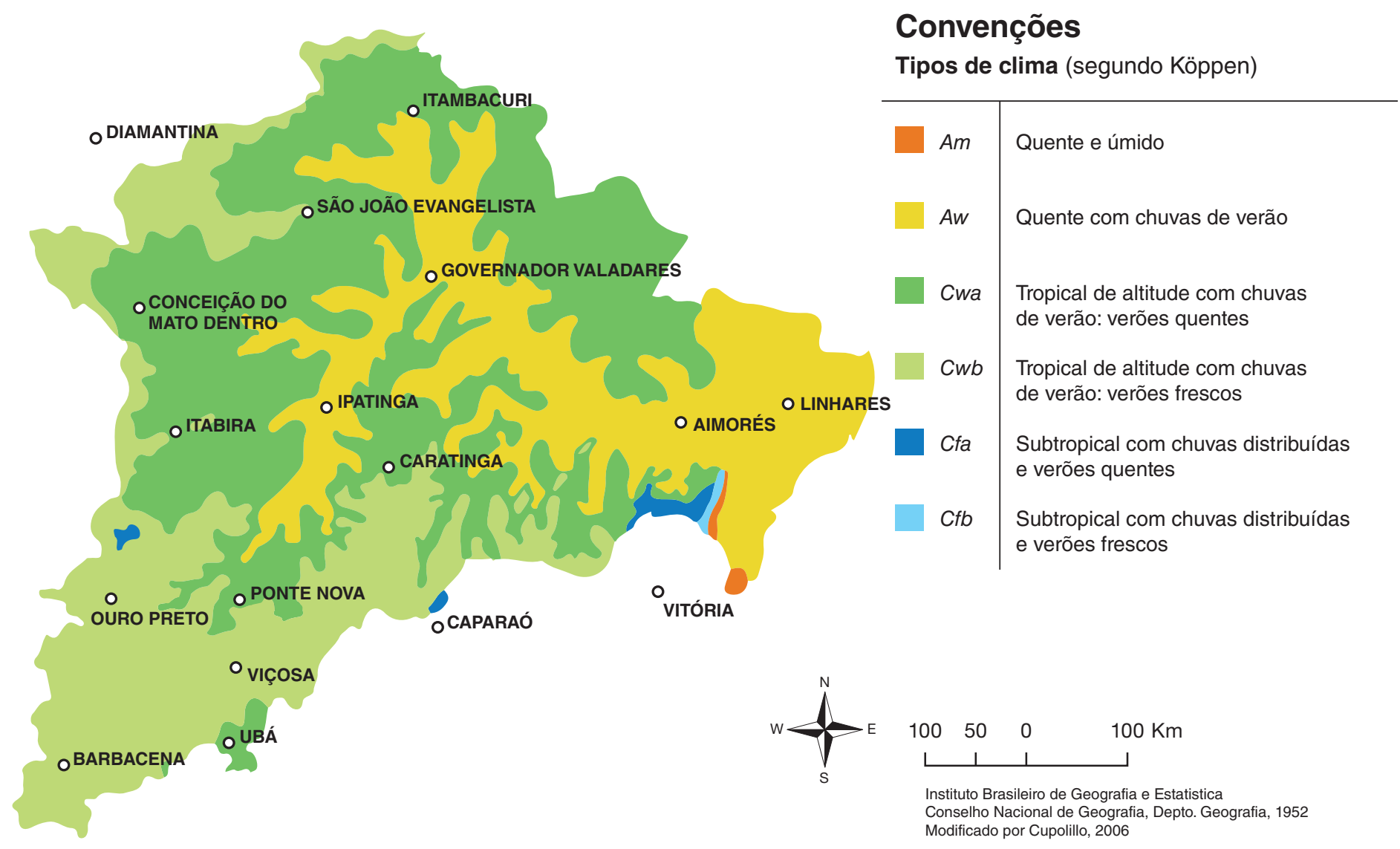

Fonte: Cupolillo et al. (2008, p. 34).

6 Desde a sua criação, em 1988, o IPCC vem lidando com a incerteza por meio da elaboração de uma série de cenários sobre a relação entre a economia humana e a mudança climática. Com esses cenários, investiga-se a ligação da intensidade das emissões de GEE com o crescimento econômico, bem como o impacto de políticas adotadas para reduzir as emissões antropogênicas desses gases. O pior cenário é o business-as-usual (manutenção do status quo), que infelizmente parece o mais provável, em vista das poucas ações corretivas adotadas para cumprir os compromissos nacionais com os objetivos da Convenção-Quadro das Nações Unidas sobre a Mudança do Clima (UNFCCC). Para mais informações, ver https://www.ipcc.ch/report/emissions-scenarios/.

7 Para mais informações, ver https://www.cptec.inpe.br/ 


\section{De forma consistente, os modelos preveem anomalias positivas de temperatura entre $2^{\circ} \mathrm{C}$ e $4^{\circ} \mathrm{C}$ no cenário mais otimista para a Bacia do Rio Doce}

no cenário mais otimista na área originalmente coberta pelo bioma Mata Atlântica, onde se insere a bacia hidrográfica do Rio Doce (IPCC, 2014b).

Em 2011, a FEAM publicou um estudo com previsões climáticas para 2080 em Minas Gerais usando o modelo climático regional desenvolvido pelo Escritório de Meteorologia Hadley Centre, do Reino Unido, chamado Providing Regional Climates for Impacts Studies, ou PRECIS. ${ }^{8}$ O estudo produziu mapas de cada sub-região econômica do estado, subsequentemente usados para elaborar projeções sobre a Bacia do Rio Doce em Minas Gerais para este estudo. Foram considerados dois cenários de emissões: (i) business-as-usual, A2-BR; ${ }^{9}$ e ii) resposta às preocupações, às atitudes e aos comportamentos da sociedade relacionados à mudança climática, B2BR (ver figura 3). Os dois cenários foram ajustados para refletir os cenários globais do IPCC.

Até onde sabemos, não foram realizadas projeções semelhantes sobre a mudança climática no Espírito Santo, embora algumas inferências sejam possíveis. ${ }^{10}$ A importância dessas projeções para a capacidade de adaptação à mudança climática faz com que o Painel recomende a ampliação desses estudos de modo a abarcar toda a Bacia do Rio Doce (ver seção 5).

Como mostra a Figura 3a, as projeções de temperatura do modelo sub-regional da FEAM apontam para um futuro mais quente na bacia hidrográfica do Rio Doce. O aumento projetado da temperatura é mais alto no cenário business-asusual $\left(3^{\circ} \mathrm{C}-3,6^{\circ} \mathrm{C}\right)$ do que no $\mathrm{B} 2-\mathrm{BR}$, o cenário mais otimista de mitigação de emissões $\left(2{ }^{\circ} \mathrm{C}-2,5,{ }^{\circ} \mathrm{C}\right)$. A

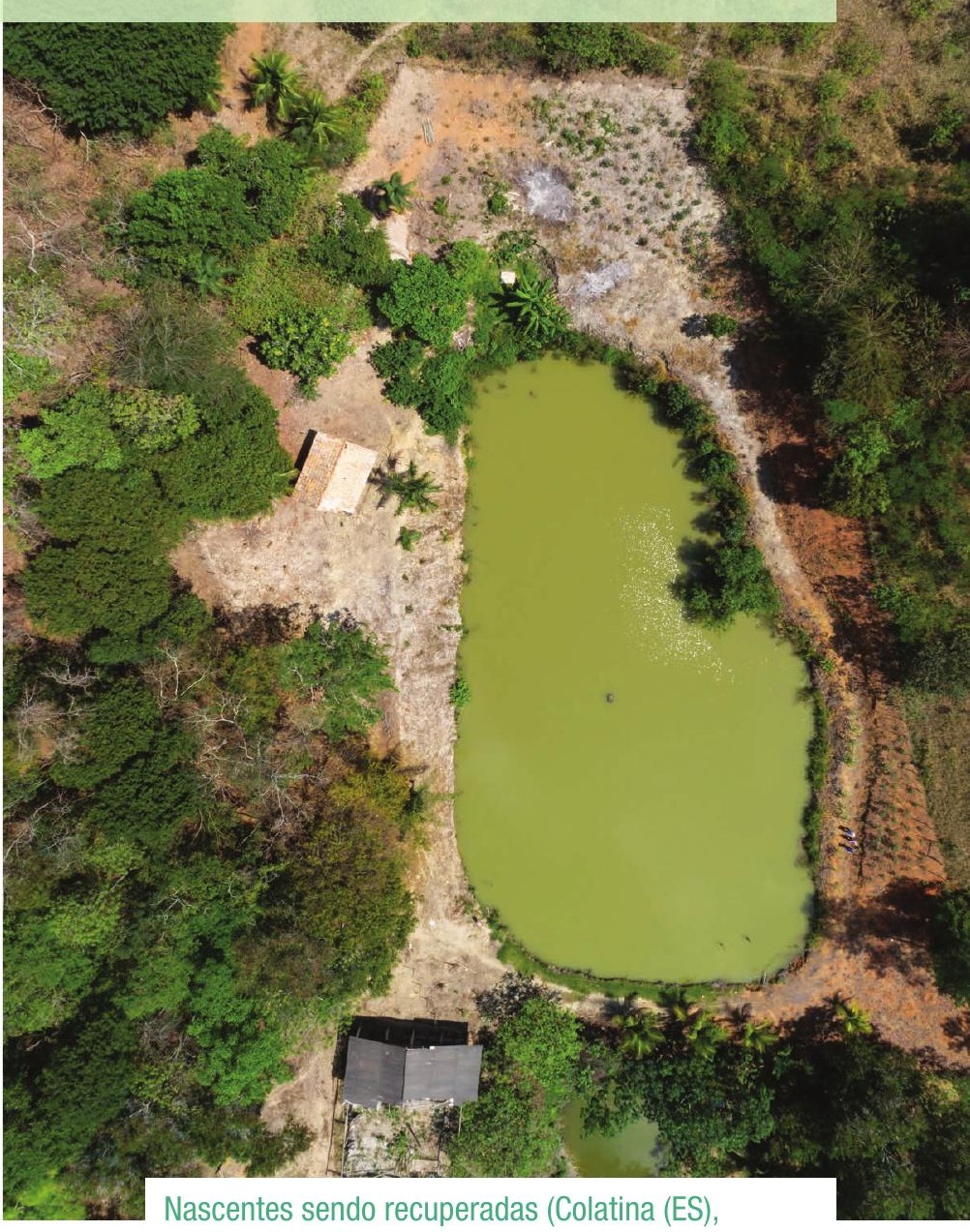
outubro de 2018)

Foto: Nitro

projeção nas partes norte e oeste da bacia indica níveis mais elevados de temperatura, com incrementos menores em direção ao litoral. Da mesma forma, o cenário business-as-usual apresenta variações mais amplas de precipitação (-1,8 a -7,6 mm entre junho e agosto) em comparação ao cenário B2-BR (-1,5 a $-6,3 \mathrm{~mm}$ entre junho e agosto). A Figura 3b mostra uma estimativa de queda nas chuvas nos dois cenários em toda a bacia durante a estação seca (inverno).

8 Para mais informações, ver https://beta.metoffice.gov.uk/research/applied/international/precis.

9 O cenário BR é específico para o Brasil, adaptado das projeções globais de mudança climática. Para mais informações, ver https://unfccc.int/files/adaptation/application/pdf/brazil_climateeconomy_executive_summary.pdf

10 O Espírito Santo aprovou uma lei em 2010 (Lei nº 9.531, de 16 de setembro de 2010) que prevê a elaboração de um plano estadual de mudança climática e incentiva ações climáticas, incluindo um programa de restauração de terras degradadas por meio de pagamentos condicionados. Em 2013, foi lançado um programa estadual de adaptação à mudança climática e preparação para desastres, incluindo instalações de alerta precoce usadas para monitoramento hidrometeorológico. 


\section{Figura 3}

Variações de temperatura (a) e precipitação (b) projetadas para 2080

na parte mineira da bacia hidrográfica do Rio Doce nos cenários A2-

BR e B2-BR

a)

$44^{\circ} 0^{\circ} 0^{\prime \prime W}$

$42^{\circ} 0^{\circ} 0^{\prime \prime} \mathrm{W}$

$40^{\circ} 0^{\prime} 0^{\prime \prime} W$

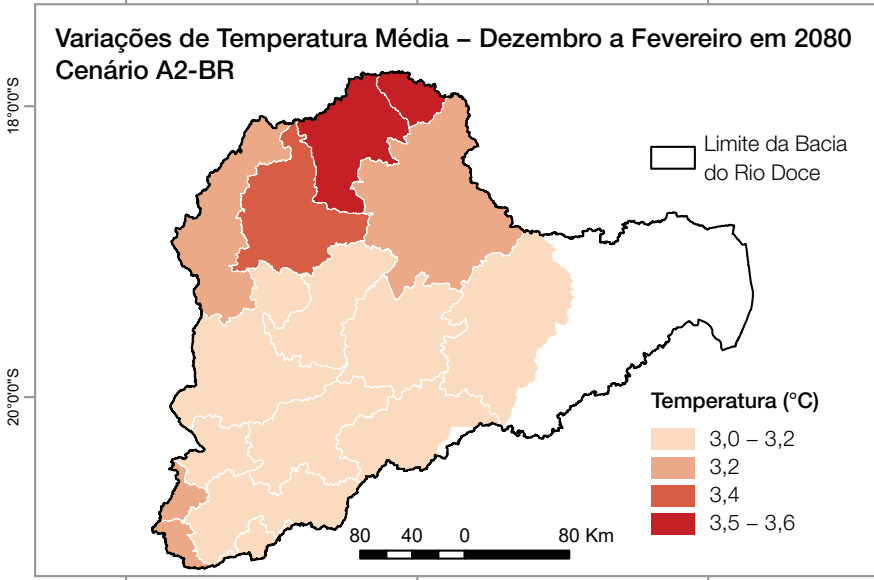

b)

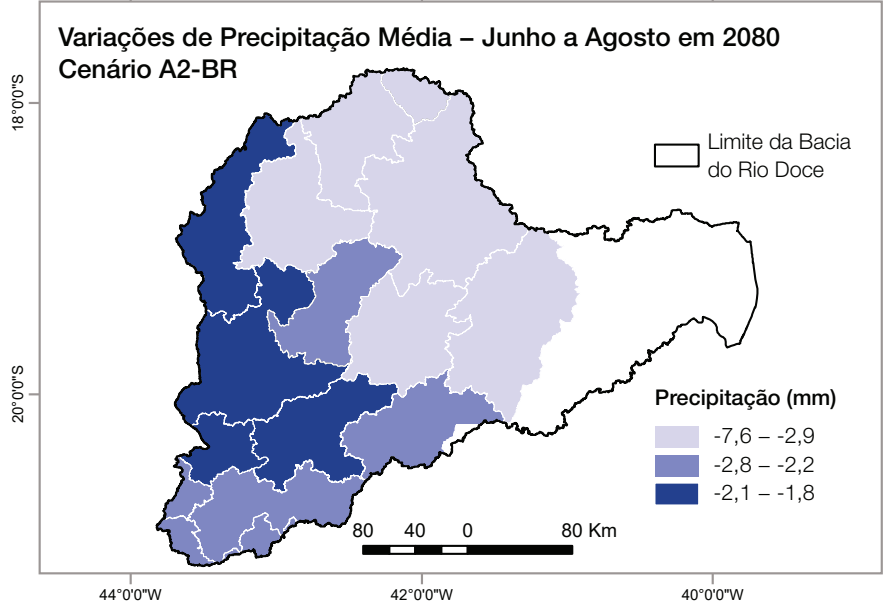

$44^{\circ} 0^{\prime} \mathrm{O}^{\circ \mathrm{W}}$

$42^{\circ} 0^{\circ} 0^{\mathrm{N} W}$

$40^{\circ} 0^{\circ} 0^{\prime \prime W}$

Variações de Temperatura Média - Dezembro a Fevereiro em 2080 Cenário B2-BR
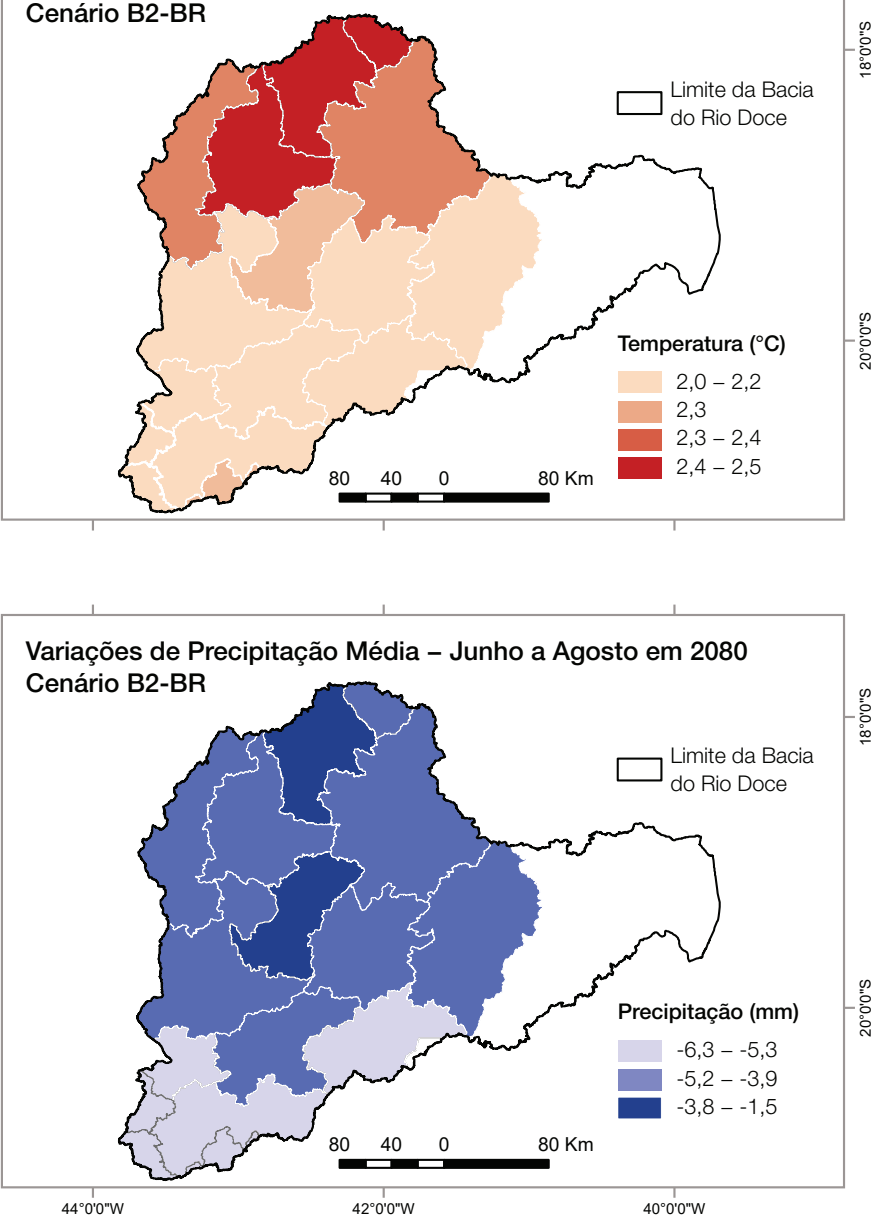

Fonte: Adaptado de FEAM (2011).

Nota: A parte branca do mapa refere-se à Bacia do Rio Doce localizada no Espírito Santo, cujo território não foi incluído no estudo original, restrito a Minas Gerais. Os delineamentos internos referem-se às sub-regiões econômicas de Minas Gerais. Originalmente, foram fornecidas previsões para todo esse estado. 
O estudo também revela que os modelos projetam um aumento de precipitação na maior parte de Minas Gerais durante a estação chuvosa (verão).

\subsection{Potencial impacto da mudança climática nas pessoas e no meio ambiente da Bacia do Rio Doce}

Com base nas previsões e nos instrumentos

mencionados anteriormente, o governo do estado de Minas Gerais previu a vulnerabilidade de suas regiões à mudança climática (FEAM, 2014). Foi examinada a sensibilidade relativa de cada sub-região e sua exposição aos impactos da mudança climática, bem como sua capacidade de adaptação. Os resultados indicaram uma sensibilidade "muito forte" à mudança climática na região do Rio Doce, o que, segundo a FEAM (2014, p. 87), pode ser atribuído a uma série de motivos, particularmente:

- parte significativa da área da bacia dedicada à silvicultura;

- alta dependência regional ao turismo;

- condições rodoviárias precárias;

- alta taxa de emigração;

- precariedade no tratamento de esgoto e na qualidade ambiental de modo geral;

- chuvas historicamente intensas; e

- risco extremamente alto de inundações.

O Quadro 1 apresenta uma matriz dos impactos da exposição à mudança climática na região da Bacia do Rio Doce, com base na análise da parte da bacia hidrográfica localizada em Minas Gerais. Nessa análise, a exposição decorre da dependência relativa, por parte de uma região específica, de atividades que requerem um regime estável de chuvas e temperaturas, paralelamente à intensidade de possíveis impactos da mudança climática no meio ambiente e na saúde humana.

A análise mostra que a bacia hidrográfica do Rio Doce está localizada em uma região considerada altamente exposta aos riscos da mudança climática. Os principais impactos surgem da possível queda de viabilidade da silvicultura e redução das terras cultiváveis, ambas associadas à menor precipitação e à perda de biodiversidade. Outros impactos da mudança climática incluem riscos à saúde humana e diminuição da capacidade de geração hidrelétrica. ${ }^{11}$

Embora não tenham sido localizados estudos detalhados e semelhantes sobre o estado do Espírito Santo, uma previsão aponta para a mesma tendência regional de redução da precipitação média mensal e aumento da temperatura média do ar de até $2,1^{\circ} \mathrm{C}$ até 2050, como aborda a Figura 4 (Pirovani, 2014).

A mesma pesquisa concluiu que a tendência é o aumento do déficit hídrico anual na maioria das regiões do estado, com o potencial de afetar ainda mais essa

\section{Quadro 1}

Exposição a impactos da mudança climática na região da Bacia do Rio Doce em Minas Gerais

\begin{tabular}{|c|c|c|}
\hline \multicolumn{2}{|c|}{ IMPACTOS DA MUDANÇA CLIMÁTICA } & $\begin{array}{l}\text { Nivel de } \\
\text { exposição }\end{array}$ \\
\hline \multirow[t]{3}{*}{ Gerais } & Aumento da temperatura & 1 \\
\hline & Redução da precipitação & 3 \\
\hline & Aumento da precipitação & 2 \\
\hline \multirow[t]{4}{*}{ Econômicos } & $\begin{array}{l}\text { Redução do produto interno } \\
\text { bruto (PIB) }\end{array}$ & 1 \\
\hline & Depleção da área de cultivo & 4 \\
\hline & Diminuição da silvicultura & 4 \\
\hline & $\begin{array}{l}\text { Redução da geração } \\
\text { hidrelétrica }\end{array}$ & 3 \\
\hline \multirow[t]{2}{*}{ Sociais } & Pressão migratória & 2 \\
\hline & Saúde humana & 3 \\
\hline \multirow[t]{2}{*}{ Ambientais } & Biodiversidade & 4 \\
\hline & Processos de desertificação & 2 \\
\hline \multicolumn{2}{|c|}{ Fonte: FEAM (2014, p. 121). } & $\begin{array}{l}\text { - Baixo } \\
\text { - Médio } \\
\text { - Forte } \\
\text { - Muito forte }\end{array}$ \\
\hline
\end{tabular}

11 A capacidade de geração hidrelétrica da Bacia do Rio Doce atende quatro grandes usinas em Minas Gerais e no Espírito Santo, totalizando mais de $810 \mathrm{~mW}$ em período de pico, e inclui a usina hidrelétrica (UHE) Risoleta Neves (Candonga), atualmente inoperante devido ao rompimento da Barragem de Fundão. 


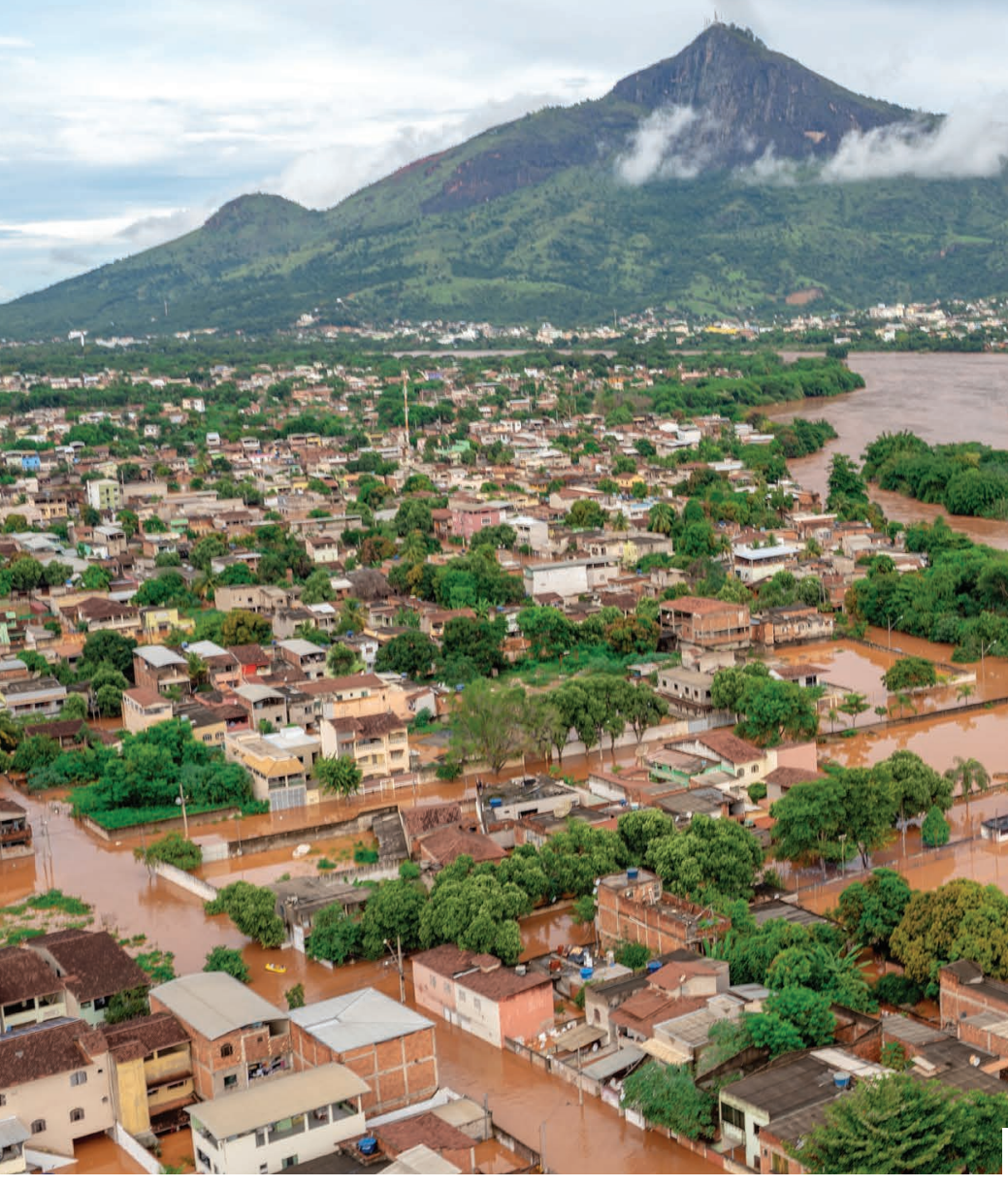




\section{Figura 4}

Cenários de mudança climática no Espírito Santo de 1982 a 2011 e em 2050: precipitação média anual (a) e temperatura média anual (b)

Precipitação média anual 1982-2011

a)

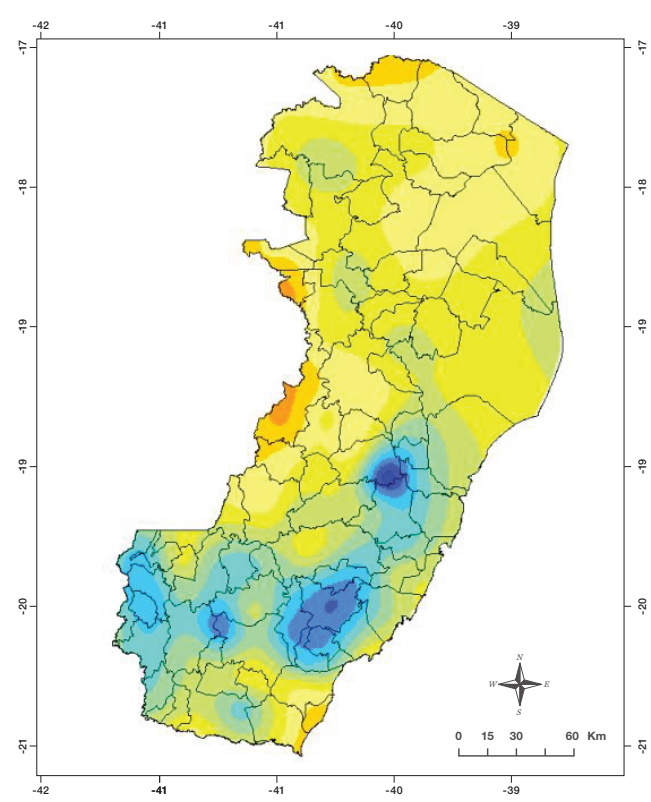

Temperatura média anual 1982-2011

b)

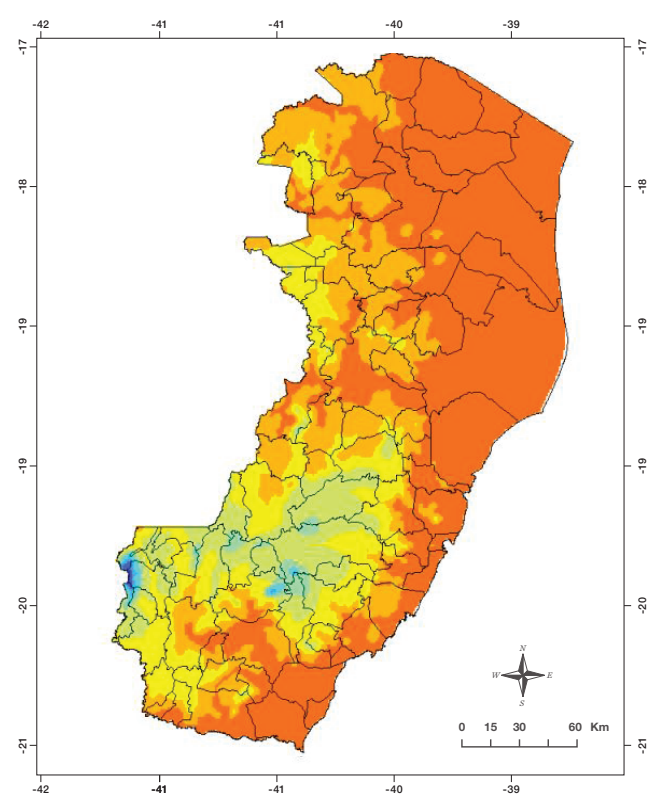

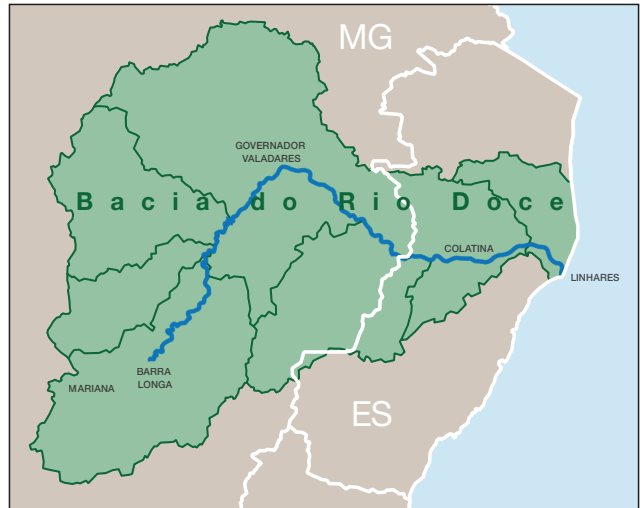

Precipitação média anual 2050

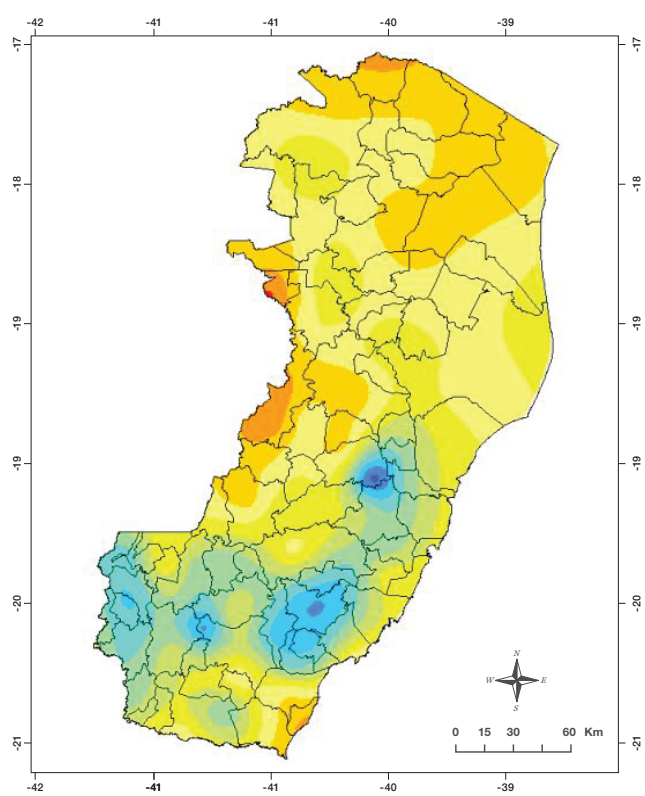

Temperatura média anual 2050

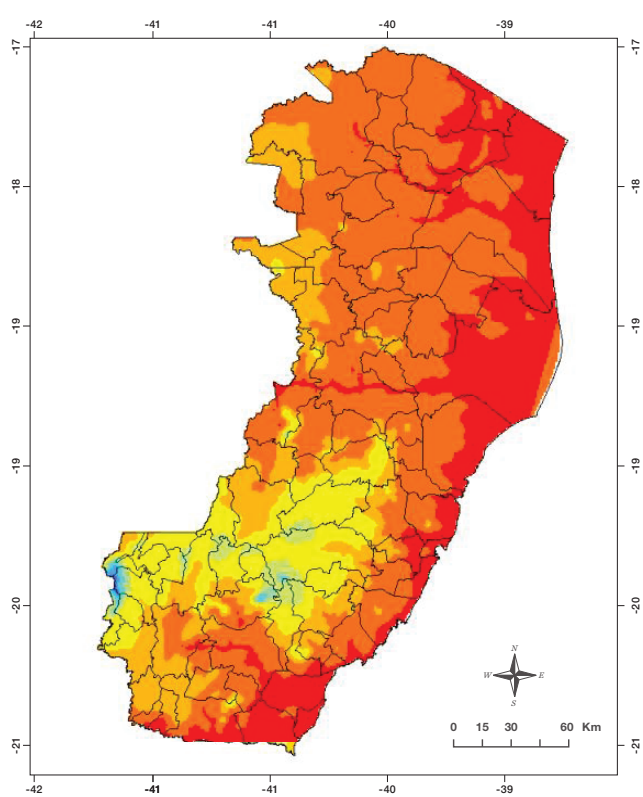

Fonte: Pirovani (2014, p. 77 (a) e p. 82 (b)). 


\section{3 | Riscos e oportunidades: passos em direção à ação climática}

\subsection{Possibilidades de ação}

Esta seção apresenta informações para subsidiar o processo decisório da Renova em ações de adaptação à mudança climática e mitigação. Abordar tal adaptação e mitigação na bacia hidrográfica do Rio Doce pode ser uma grande oportunidade para revisitar os programas de restauração já em andamento e refinar as sinergias. As ações climáticas também podem ser uma ferramenta importante de integração dos programas, já que o tema exige uma perspectiva interdisciplinar. Não há dúvida de que essa oportunidade posicionaria o esforço de restauração do Rio Doce na vanguarda das ações nacionais e internacionais de preparação para a mudança climática.

Na medida em que a Renova dá continuidade à implementação dos 42 programas previstos no TTAC, este é um momento fundamental para engajar o esforço de restauração do Rio Doce na construção de um caminho para a ação climática. Reconhecendo que o risco traz oportunidades, os esforços de restauração representam novas oportunidades para a Renova e os municípios do Rio Doce, que podem ser positivamente sincronizadas com uma estratégia coordenada em prol do planejamento de ações climáticas na Bacia. ${ }^{12}$ A Renova possui uma gama de opções estratégicas para contribuir para esse resultado, usando uma abordagem amplamente adotada no setor corporativo por meio de práticas de gestão de carbono (Lee \& Lee, 2018).

Neste relatório, destaca-se a importância de compreender os detalhes e as repercussões da mudança climática, desde o planejamento inicial das atividades da Renova até depois de sua implementação. Como se trata de uma questão transversal, há uma variedade de ações e propostas específicas que podem ser adotadas, que não serão possíveis de descrever em detalhes neste relatório, mas que podem ser desenvolvidas por meio de um esforço coordenado de gestão. Três temas, no entanto, se destacam e são aprofundados nesta seção:

i) adaptação à mudança climática;

ii) oportunidades de sequestro de carbono em sistemas naturais; e

iii) estratégias para eficiência energética, uso e geração de energia.

\subsection{Adaptação à mudança climática nos programas do TTAC}

O fortalecimento da capacidade de adaptação exige atenção às variáveis institucionais e de capital social, como coordenação, redes sociais de atores, fluxos de informação e tomada de decisão de forma participativa. Esses fatores são considerados nesta seção na medida em que interagem tanto com os esforços de restauração dos ecossistemas e compensação dos danos, por meio dos programas do TTAC em execução pela Renova, quanto com a necessidade de esforços complementares de longo prazo por parte dos parceiros da Renova nos níveis estadual e municipal. Essa abordagem garante uma estratégia de transição em apoio à aprendizagem institucional (Rotmans \& Loorbach, 2009).

Em circunstâncias ideais, os efeitos da mudança climática devem ser levados em consideração durante as fases de planejamento, monitoramento e avaliação. Embora o desenho dos 42 programas do TTAC não tenha considerado a mudança climática explicitamente, informações sobre previsões climáticas e impactos previstos em parte da bacia do Rio Doce estavam disponíveis para os tomadores de decisão que participaram da definição dos programas do TTAC 



\begin{tabular}{|c|c|c|c|c|c|c|}
\hline NÚMERO E TÍTULO DO PROGRAMA & $\begin{array}{l}\text { MUDANÇA DE } \\
\text { TEMPERATURA }\end{array}$ & $\begin{array}{l}\text { REDUCC̄̃O DA } \\
\text { PRECIPTACĀÃO }\end{array}$ & $\begin{array}{l}\text { SECAS } \\
\text { SEVERAS }\end{array}$ & $\begin{array}{l}\text { CHUVAS } \\
\text { INTENSAS }\end{array}$ & $\begin{array}{l}\text { EROSÃO } \\
\text { COSTEIRA }\end{array}$ & $\begin{array}{l}\text { AUMENTO DO } \\
\text { NIVEL DO MAR }\end{array}$ \\
\hline $\begin{array}{l}3 \text { - Proteção e Recuperação da Qualidade de } \\
\text { Vida dos Povos Indígenas }\end{array}$ & & & & & & \\
\hline $\begin{array}{l}4 \text { - Proteção e Recuperação da Qualidade de } \\
\text { Vida de Outros Povos e Comunidades } \\
\text { Tradicionais }\end{array}$ & & & & & & \\
\hline 8 - Reconstrução de Vilas & & & & & & \\
\hline $\begin{array}{l}9 \text { - Recuperação do Reservatório da UHE } \\
\text { Risoleta Neves (Candonga) }\end{array}$ & & & & & & \\
\hline $\begin{array}{l}10 \text { - Programa de Recuperação das Demais } \\
\text { Comunidades e Infraestruturas Impactadas } \\
\text { entre Fundão e Candonga }\end{array}$ & & & & & & \\
\hline $\begin{array}{l}11 \text { - Recuperação das Escolas e Reintegração } \\
\text { da Comunidade Escolar }\end{array}$ & & & & & & \\
\hline $\begin{array}{l}13 \text { - Programa de Turismo, Cultura, Esporte } \\
\text { e Lazer }\end{array}$ & & & & & & \\
\hline $\begin{array}{l}14 \text { - Programa de Apoio à Saúde Física e Mental } \\
\text { da População Impactada }\end{array}$ & & & & & & \\
\hline $\begin{array}{l}16 \text { - Retomada das Atividades Aquícolas } \\
\text { e Pesqueiras }\end{array}$ & & & & & & \\
\hline 17 - Retomada das Atividades Agropecuárias & & & & & & \\
\hline 23 - Manejo de Rejeitos & & & & & & \\
\hline 24 - Contenção de Rejeitos e Tratamento de Rios & & & & & & \\
\hline $\begin{array}{l}25 \text { - Revegetação, Enrocamentos e Outros } \\
\text { Métodos }\end{array}$ & & & & & & \\
\hline $\begin{array}{l}26 \text { - Programa de Recuperação de Áreas } \\
\text { de Preservação Permanente (APPs) } \\
\text { e Recargas Hídricas }\end{array}$ & & & & & & \\
\hline 27 - Programa de Recuperação de Nascentes & & & & & & \\
\hline 28 - Conservação da Biodiversidade & & & & & & \\
\hline 29 - Recuperação da Fauna Silvestre & & & & & & \\
\hline 30 - Fauna e Flora Terrestre & & & & & & \\
\hline $\begin{array}{l}31 \text { - Coleta e Tratamento de Esgoto e Destinação } \\
\text { de Resíduos Sólidos }\end{array}$ & & & & & & \\
\hline $\begin{array}{l}32 \text { - Melhoria dos Sistemas de Abastecimento } \\
\text { de Água }\end{array}$ & & & & & & \\
\hline 38 - Monitoramento da Bacia do Rio Doce & & & & & & \\
\hline 39 - Unidades de Conservação & & & & & & \\
\hline
\end{tabular}


O Quadro 2 lista todos os programas de restauração incluídos no TTAC e sob a responsabilidade da Renova que, na avaliação do Painel, apresentam evidências de vulnerabilidade aos impactos da mudança climática. Cada programa envolve ações específicas cujos resultados podem ser ameaçados por um ou mais dos seis principais impactos esperados na Bacia do Rio Doce.

Considera-se que a análise representa o primeiro nível de uma avaliação multinível para distinguir os programas e resultados mais suscetíveis aos efeitos da mudança climática. Após revisão pelos grupos internos de trabalho da Renova em consulta com as partes interessadas e os órgãos colaboradores do governo, os programas identificados como especialmente suscetíveis podem ser reforçados e/ou redirecionados para garantir maior resiliência aos impactos da mudança climática em nível regional. Tal reforço deve dar a devida atenção à capacidade adaptativa. Por esse motivo, foram identificados outros programas do TTAC (notadamente o programa de Diálogo Social, 6; Educação Ambiental, 33; e Preparação para Emergências Ambientais, 34) que têm um papel indireto, embora transversal, nos demais programas, pois podem ajudar a fortalecer as capacidades adaptativas.

Conforme mostra o Quadro 2, nem todos os programas e resultados foram classificados como vulneráveis a impactos climáticos. No entanto, vários grupos de programas devem receber atenção para garantir sua eficácia. Dos 42 programas do TTAC, 20 podem estar diretamente ameaçados e 3 indiretamente ameaçados por algum aspecto dos efeitos da mudança climática. A seguir, são descritos possíveis impactos previstos da mudança climática na bacia e como eles podem afetar os resultados dos programas de restauração em andamento no âmbito do TTAC.

Programas ambientais, como os de renaturalização de cursos d'água e isolamento e proteção de APPs e nascentes - a exemplo do Programa de Revegetação, Enrocamentos e Outros Métodos (25), do Programa de Recuperação de APPs e Recargas Hídricas (26) e do Programa de Recuperação de Nascentes (27) -, prestam serviços ambientais que ajudam na resiliência a extremos climáticos nos sistemas de produção rural. Embora seus resultados possam ser vulneráveis, esses programas têm o potencial de aumentar a resiliência e evitar a vulnerabilidade se conseguirem se adaptar às ameaças climáticas. Por exemplo, a ocorrência de secas severas ou a redução das chuvas pode ter um forte efeito na sobrevivência das mudas usadas em programas de revegetação, gerando custos mais elevados devido à necessidade de repetir o plantio. Ao mesmo tempo, longas secas podem ameaçar a sobrevivência das árvores e deixá-las mais vulneráveis a incêndios. A seleção de espécies com base na tolerância à seca e a irrigação durante o período de estabelecimento desses plantios podem ser incluídas como medidas adaptativas.

No caso do Programa de Revegetação, Enrocamentos e Outros Métodos (25), as inundações podem danificar as estruturas de contenção dos canais e impedir a conservação do solo nas margens dos rios e a deposição de sedimentos. A insuficiência de chuvas, por outro lado, pode prejudicar a produtividade dos sistemas agroflorestais e de rotação de pastagens; já os eventos intensos de chuva podem lavar a camada superior do solo e acentuar a degradação das pastagens (Programa Retomada das Atividades Agropecuárias, 17). Esses efeitos adversos precisam ser equilibrados com esforços de capacitação local para responder a extremos climáticos, com o apoio de serviços de extensão local, nos casos em que as intervenções estruturais requeiram adaptações de projeto para se ajustar a eventos extremos de chuva. Essas abordagens estão alinhadas com experiências internacionais bem-sucedidas de conservação e gestão integrada da paisagem, que visam garantir a resiliência dos agroecossistemas locais à mudança climática (Scherr, Shames, \& Friedman, 2012).

O componente de Uso Sustentável da Terra da Renova, responsável pela coordenação das intervenções rurais na Bacia do Rio Doce, tem sido proativo em garantir que as medidas de adaptação a impactos climáticos sejam levadas em consideração 
no planejamento das atividades de restauração. Elas envolvem uma avaliação detalhada, com o georreferenciamento de fatores ecológicos, abióticos e socioeconômicos capazes de afetar o sucesso das atividades de restauração, bem como o recurso à regeneração natural em vez de depender unicamente do plantio de mudas, que seria relativamente mais arriscado. A Renova também deu atenção especial aos riscos de incêndio florestal em suas atividades de restauração, equipando e treinando brigadas de incêndio locais.

Outros programas associados à conservação da natureza, como os de Conservação da Biodiversidade (28), Recuperação da Fauna Silvestre (29), Fauna e Flora Terrestre (30) e Coleta e Tratamento de Esgoto e Destinação de Resíduos Sólidos (31), podem ser afetados pelo aumento das temperaturas e pela redução das chuvas, que, juntos, elevam o risco de incêndio e outros impactos adversos na biodiversidade. Essas mudanças também podem alterar a riqueza e a variedade das espécies e os serviços ambientais que elas oferecem, além de impactar as atividades econômicas extrativistas. $\mathrm{Na}$ zona costeira e nas áreas estuarinas da Bacia do Rio Doce, os objetivos de conservação da biodiversidade podem ser prejudicados pelo aumento do nível do mar, que teria efeitos indesejados nos locais de nidificação e na migração ao longo do litoral e das áreas costeiras, além de alterações na biota de água do mar.

O alcance dos objetivos globais de conservação da natureza e a garantia de resposta adequada às previsões de mudança climática exigem a criação de mais áreas protegidas em biomas terrestres e aquáticos. Uma revisão internacional das medidas necessárias para garantir o sucesso da adaptação de espécies e ecossistemas à mudança climática mostra que as abordagens mais eficazes vão além de assegurar a sobrevivência das espécies que atualmente ocorrem em determinada paisagem (Watson et al., 2012). De fato, é necessário integrar o planejamento das áreas protegidas para refletir a potencial resposta de adaptação das espécies à mudança climática e monitorar essa resposta para ajustar os planos com o passar do tempo. No contexto do Rio Doce, isso sugere a necessidade não apenas de ampliar a rede de áreas protegidas, mas também de planejar e elaborar medidas adaptativas ao passo que a mudança climática ocorre na Bacia.

O abastecimento hídrico e a estabilidade das vazões de água são os principais serviços ambientais promovidos pelo manejo integrado de paisagens e pela ampliação das áreas protegidas.

No caso específico da Qualidade de Vida dos Povos Indígenas e de outros Povos e Comunidades Tradicionais, questão tratada nos Programas 3 e 4, esta pode ser afetada pela redução da disponibilidade de água em períodos de seca prolongada. Daí a necessidade de adaptar os planos a fim de ampliar as infraestruturas de abastecimento hídrico para uso em épocas de escassez.

Além disso, a Reconstrução de Vilas (Programa 8) exige medidas adaptativas para garantir a estabilidade das encostas nos eventos intensos de chuva previstos com a mudança climática. Visto que esses impactos ainda seriam sentidos muito tempo após a conclusão da reconstrução programada no âmbito do TTAC, a readaptação invariavelmente acarretaria custos adicionais e atrasos na entrega das moradias. Os esforços envidados pela Renova para proteger as moradias da instabilidade das encostas são dignos de nota.

A prestação de serviços adequados de Apoio à Saúde Física e Mental da População Impactada (Programa 14) pode ser ameaçada pelo aumento da temperatura, bem como por fatores associados à provisão de água potável, cuja disponibilidade e tratamento são essenciais para a saúde pública. Esses serviços estão entrelaçados com os Programas de Melhoria dos Sistema de Abastecimento de Água (32) e Monitoramento da Bacia do Rio Doce (38), que podem ser ameaçados pela maior ocorrência de eventos extremos, como inundações. 


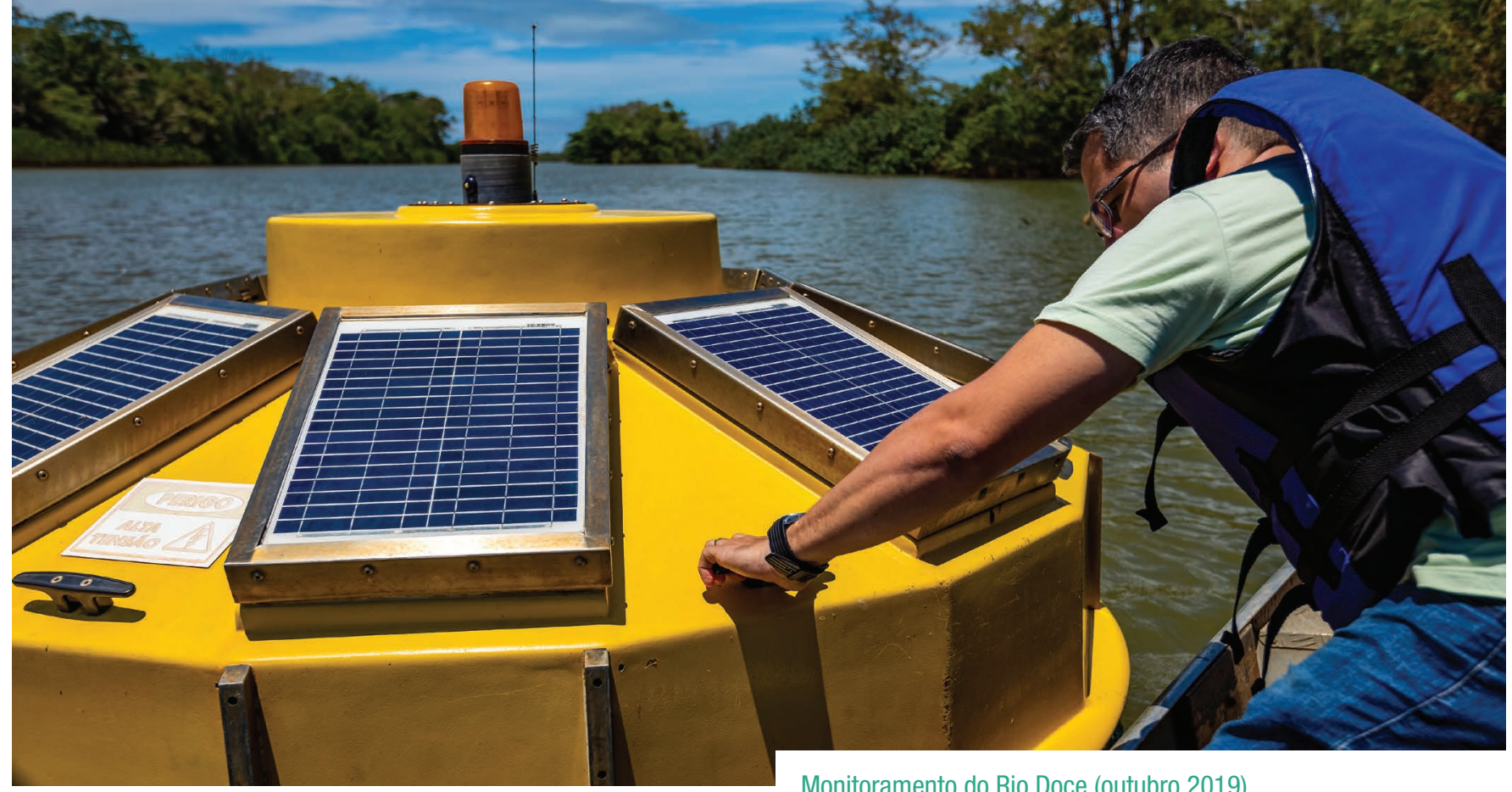

Monitoramento do Rio Doce (outubro 2019)

Foto: NITRO.

Nesse contexto, o artigo Questões em Foco no 5 do Painel do Rio Doce sobre as interconexões entre a saúde humana e a saúde dos ecossistemas recomenda que a Renova desenvolva capacidades para monitorar os impactos na saúde e no meio ambiente, aumentando o envolvimento dos membros das comunidades (Alonso et al., 2020). Essa capacitação deve incluir ações de conscientização sobre os impactos da mudança climática na saúde e no meio ambiente. A adoção de uma abordagem integrada de saúde humana e saúde dos ecossistemas, que leve em consideração a mudança climática e possa ser incluída no projeto proposto pela Renova de Gestão Ambiental Integrada para Saúde e Meio Ambiente (Gaisma), pode facilitar a resposta nessa área de vulnerabilidade climática.

Entre os programas transversais, até que os efeitos da mudança climática sejam integrados efetivamente nas ações da Renova, os resultados do Programa de Preparação para Emergências Ambientais (34) não conseguirão reagir a todos os cenários possíveis - principalmente considerando-se que incêndios florestais, secas e eventos extremos de chuva devem se tornar mais recorrentes e intensos com a mudança climática. Nesse sentido, o apoio da Renova à preparação de brigadas de incêndio locais já fez uma contribuição para permitir a adaptação à mudança climática.
Consultas com atores locais sobre infraestruturas ou redes de comunicação podem ser feitas por meio do Programa de Comunicação, Participação, Diálogo e Controle Social (6) visando canalizar os recursos para capacitação em adaptação para onde forem mais necessários. De modo geral, entende-se que a educação ambiental (Programa de Educação para Revitalização da Bacia do Rio Doce, 33) e a comunicação social aumentam a capacidade da população de se adaptar e responder à mudança climática. Portanto, deve ser enfatizada a importância primordial do capital social, das capacidades institucionais, da liderança local e da participação das pessoas afetadas.

\subsection{Oportunidades de sequestro de carbono em sistemas naturais}

Globalmente, o desmatamento e a degradação florestal liberam cerca de 4,4Gt de dióxido de carbono equivalente $\left(\mathrm{CO}_{2} \mathrm{eq}\right)$ por ano na atmosfera (Matthews \& van Noordwijk, 2014), ou aproximadamente 12\% das emissões de $\mathrm{CO}_{2}$ eq antropogênico (IPCC, 2014a). Se forem considerados a agricultura, a silvicultura e outros usos da terra, suas contribuições representam em torno de $24 \%$ das emissões antropogênicas anuais globais. A prevenção dessas emissões, por meio de ações aprimoradas de conservação e manejo do uso da terra, é uma intervenção poderosa e pode 
representar uma grande contribuição para os esforços globais de mitigação (Cohen-Shacham et al., 2016).

Na bacia do Rio Doce - onde a agricultura e a mudança no uso da terra têm histórico de gestão deficiente -, a regeneração da vegetação nativa é uma maneira de compensar as emissões de GEE, pois possibilita a absorção de carbono nas florestas através de

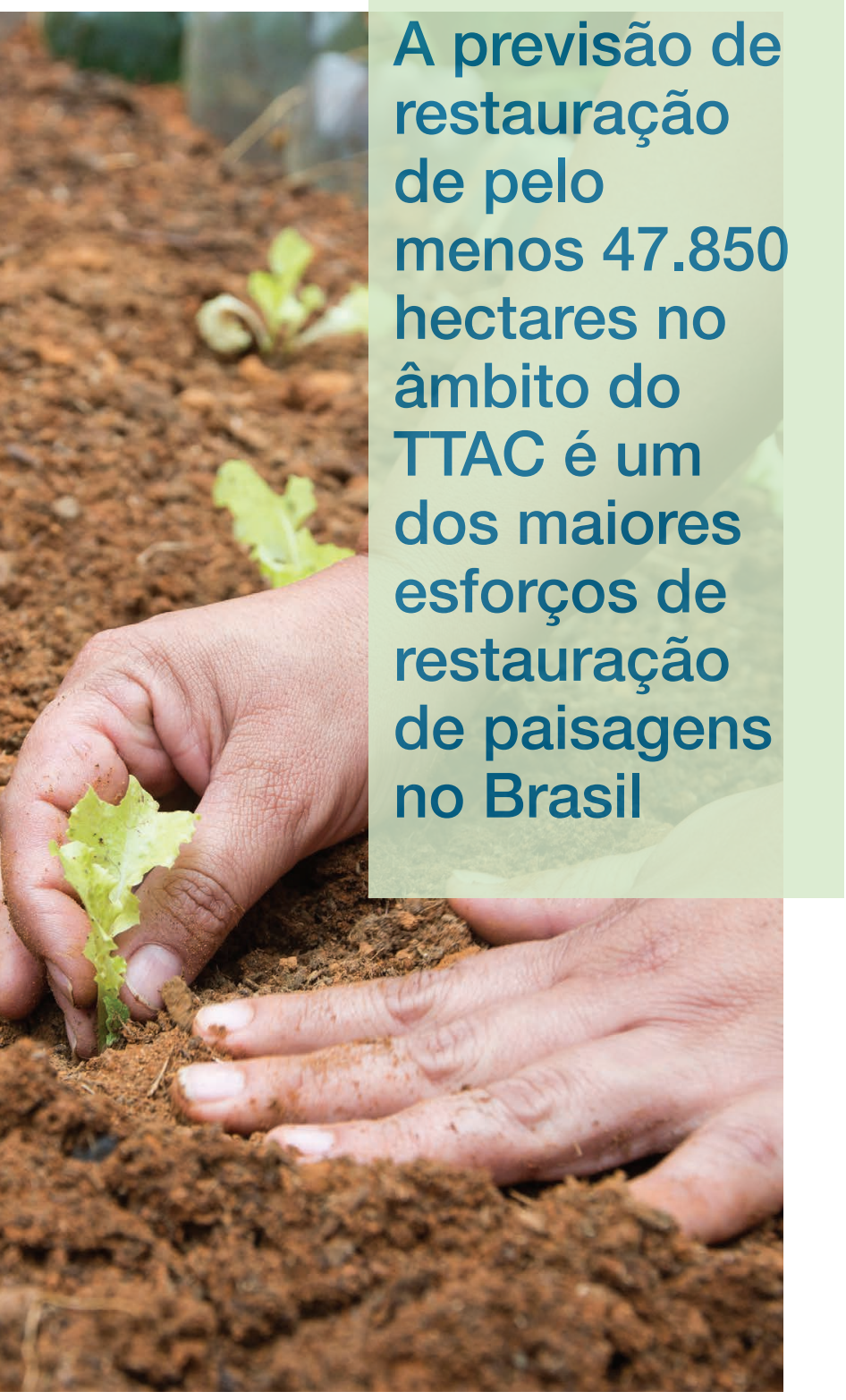

processos naturais. Uma estratégia de restauração da paisagem também possibilitaria a recuperação das funções e dos processos ecossistêmicos, renovando a disponibilidade de água para necessidades humanas e animais, além de reconstituir as cadeias alimentares e a ação microbiana nos solos e diminuir a erosão. O reflorestamento industrial é outro meio de aumentar os estoques florestais de carbono, mas dificilmente poderá atingir o mesmo nível de restauração das funções ecossistêmicas.

O estoque médio de carbono armazenado em florestas nativas secundárias no bioma Mata Atlântica foi calculado em 47 toneladas de C/ha, com base em medições na bacia do Rio Paraíba do Sul (Ronquim et al., 2016). Na ausência de um monitoramento mais específico, esse valor pode ser considerado representativo do potencial médio de sequestro de carbono acima do solo das florestas secundárias nativas da bacia hidrográfica do Rio Doce. O potencial de armazenamento de carbono acima do solo é complementado pelo sequestro de carbono em solos sujeitos à regeneração florestal secundária.

A tecnologia atualmente usada na Bacia do Rio Doce pela Fundação Renova para restaurar a vegetação nativa enfatiza a revegetação das margens e nascentes. Também houve esforços para melhorar a cobertura vegetal das encostas por meio do enriquecimento com espécies frutíferas e outras plantas lenhosas. A definição estratégica das áreas de maior prioridade física e socioeconômica em termos de reflorestamento e agrossilvicultura incluiu o potencial de geração de renda e a proteção de recursos naturais e ecossistemas (Fundação Renova et al., 2018).

Se considerarmos a previsão de restauração de 42.500 hectares no âmbito do TTAC, ${ }^{14}$ isso pode aumentar em aproximadamente 2 milhões de tC o potencial total de armazenamento de carbono da biomassa acima do solo. Embora represente apenas

14 Equivalente à soma de 40.000 hectares de áreas de preservação permanente ou recarga hídrica, de acordo com o novo Código Florestal (conforme a Cláusula 161 do TTAC), e revegetação em torno de 5.000 nascentes (conforme a Cláusula 163 do TTAC) sendo que, em cada uma, está prevista a revegetação de 0,5 hectare em média. 
uma pequena parcela para os compromissos da Contribuição Nacionalmente Determinada (CDN) do Brasil no âmbito do Acordo de Paris - que compreendem a restauração líquida de 12 milhões de hectares de terras degradadas até 2030 (Brasil, 2015) -, esse seria um dos maiores esforços de restauração de paisagens florestais no país. A Renova e as agências parceiras têm todo o direito de reivindicar para si o crédito por essa contribuição para a mitigação climática. Essas oportunidades têm o potencial de atrair investimentos de indústrias que procuram compensações (offsets) de carbono emitido, incluindo o setor de mineração (ver seção 4.1).

\subsection{Estratégias para eficiência energética, uso e geração de energia}

O setor energético é o maior contribuinte para as emissões globais de GEE; a geração e o uso de energia, incluindo o transporte, são responsáveis por cerca de dois terços das emissões globais (Crippa et al., 2019). No Brasil, dados do Sistema de Registro Nacional de Emissões (Sirene) indicam que, em 2016 (o último ano inventariado), as emissões anuais do setor energético, de $422.498 \mathrm{Gg} \mathrm{CO}_{2} \mathrm{eq}$, superaram emissões de outros setores, como a mudança nos usos da terra e florestas. ${ }^{15}$ Essa tendência também é observada em Minas Gerais, onde se estimava que as emissões do setor energético superariam as fontes agrícolas até 2020 (FEAM, 2015). Da mesma forma, em 2006 os processos industriais e as emissões de energia excederam as emissões associadas à agricultura e às mudanças no uso da terra e florestas no Espírito Santo (Lorena et al., 2013). Houve, portanto, um aumento da importância relativa das emissões relacionadas a energia para as ações de mitigação da mudança climática no Brasil. ${ }^{16}$

Para medir suas emissões de GEE, as organizações e empresas costumam realizar um inventário dessas emissões, analisando seu consumo de energia de acordo com os processos, os tipos e as quantidades de combustível e seus respectivos níveis de emissões no estágio atual de evolução tecnológica. Essas emissões são usualmente classificadas em "escopos": o Escopo 1 refere-se às emissões diretamente originárias das ações de uma organização e sob seu controle direto; o Escopo 2 refere-se às emissões indiretas provenientes da aquisição de energia elétrica e térmica que é consumida pela empresa; e o Escopo 3 refere-se às outras emissões indiretas, por exemplo, extração e produção de matériasprimas (WBCSD \& WRI, 2004). A geração e o uso de energia oferecem um potencial considerável para investimentos em tecnologias e iniciativas de baixo carbono, com a possibilidade de estabilizar - e talvez até reduzir - as emissões gerais de GEE, incluindo ações associadas ao uso sustentável da terra.

A Renova pode seguir dois caminhos: tanto eficiência energética quanto energia renovável.

\section{- Eficiência energética}

Eficiência energética (EE) significa o uso de menos energia para atingir os mesmos resultados. Além de reduzir as emissões de GEE, ela reduz a demanda por energia importada, diminuindo os custos operacionais. Melhorar a EE é a maneira mais barata e, muitas vezes, mais imediata de reduzir o uso de combustíveis fósseis. Existem diversas oportunidades de melhorar a eficiência dos processos empreendidos pela Renova, como transporte, construção, uso de máquinas na restauração de margens de rios e remoção de rejeitos.

\section{- Energia renovável}

Além de apresentar grande potencial de mitigação da mudança climática, a energia renovável (ER) proporciona benefícios mais amplos. Se bem

15 Para mais informações, ver https://www.mctic.gov.br/mctic/opencms/indicadores/detalhe/dados_setor_comunicacoes/SIRENE. html

16 É importante ressaltar que essa mudança na importância relativa das emissões setoriais em nível nacional deveu-se ao sucesso do Brasil na redução da taxa de desmatamento entre 2005 e 2015. Esse sucesso, no entanto, vem se desfazendo desde 2015 (SEEG, s.d.). 


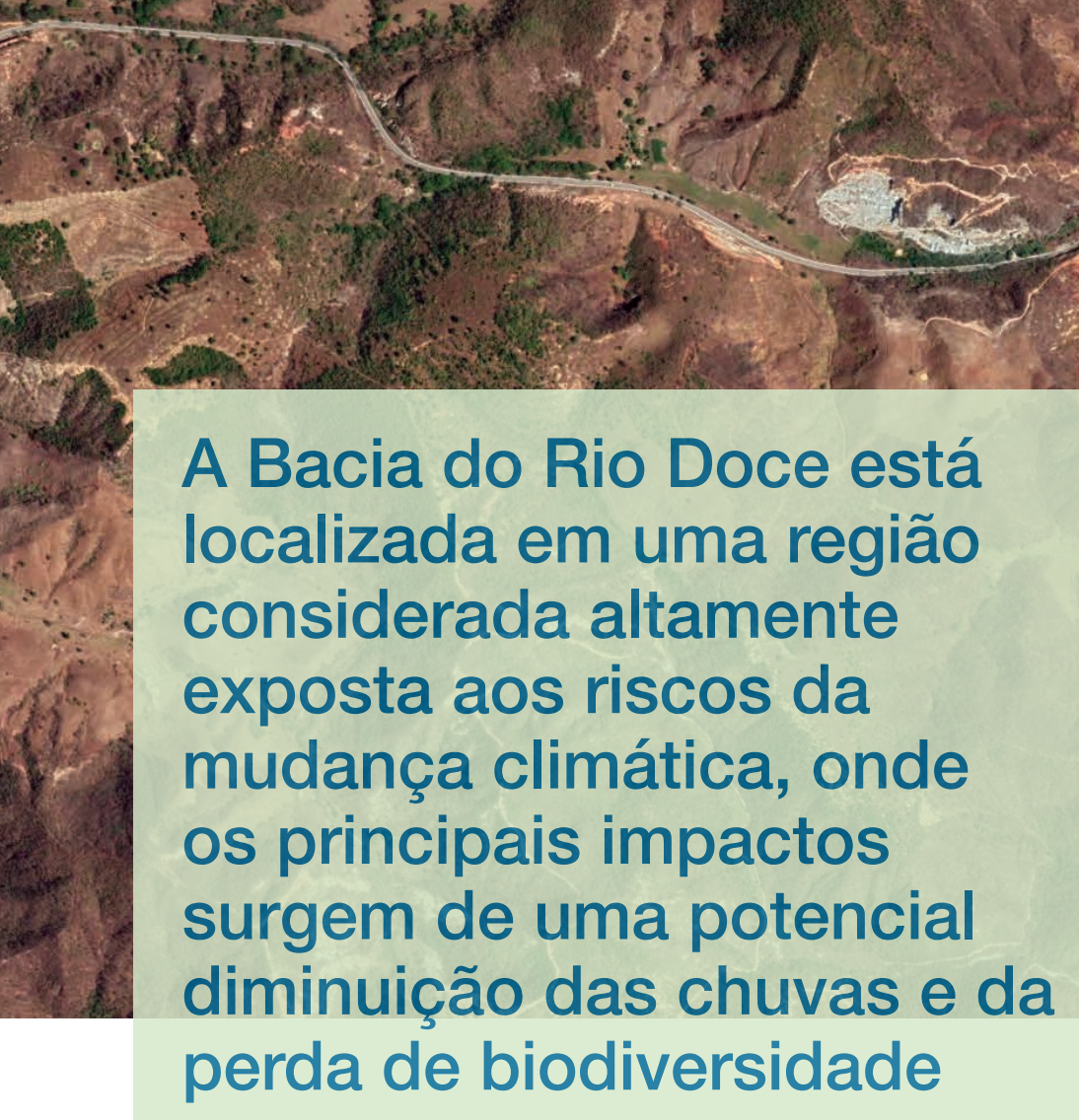 \\ A Bacia do Rio Doce está localizada em uma regiáo considerada altamente exposta aos riscos da mudança climática, onde os principais impactos surgem de uma potencial diminuição das chuvas e da perda de biodiversidade}

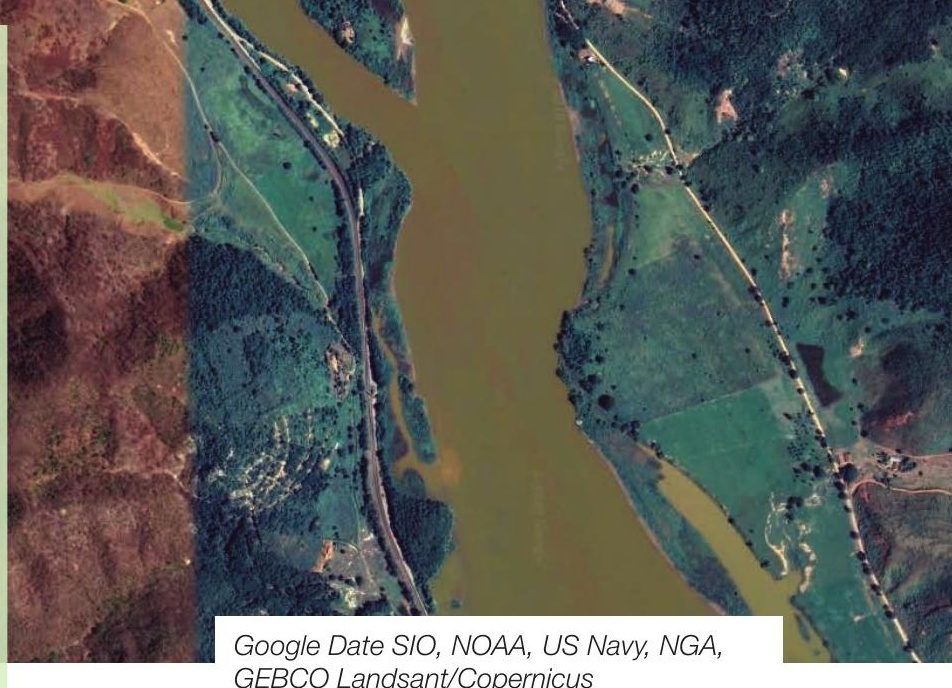
GEBCO Landsant/Copernicus

implementada, pode contribuir para o desenvolvimento social e econômico, o acesso à energia, o fornecimento seguro de energia e a redução dos impactos negativos no meio ambiente e na saúde (IPCC, 2014). O potencial de integração da ER nos programas do TTAC deve ser determinado e avaliado. Nessa área, algumas alternativas são a mudança para combustíveis fósseis renováveis ou menos intensivos em carbono e a geração de energia solar ou eólica.

Em relação aos processos da Renova, a EE e as ERs devem ser avaliadas à luz dos 42 programas do TTAC. Embora o Painel entenda que a Renova já esteja implementando iniciativas de EE e ER em vários programas, seria importante realizar uma revisão coordenada e da perspectiva de gestão do carbono.
A experiência mostra que algumas iniciativas podem ser adotadas com facilidade, sem grandes mudanças nos orçamentos e cronogramas dos programas. Na realidade, alguns dos esforços de redução das emissões de GEE associadas à energia, se planejados e executados corretamente, podem reduzir os custos de investimento de forma considerável. Assim como nas iniciativas de sequestro de carbono, podem surgir oportunidades interessantes - em termos de financiamento e imagem - com a implementação de projetos de mitigação relacionados a energia.

O Quadro 3 lista os programas que podem apresentar oportunidades diretas de redução das emissões de GEE relacionadas à EE e às ERs. Apresenta, também, algumas ações que podem ser implementadas. 


\section{Quadro 3}

Oportunidades de promover ou aumentar a eficiência energética

e 0 uso de energia renovável em programas do TTAC

\section{NÚMERO E TÍTULO DO PROGRAMA}

8 - Reconstrução de Vilas

\section{9 - Recuperação do Reservatório da UHE} Risoleta Neves (Candonga)

\section{0 - Programa de Recuperação das Demais Comunidades e Infraestruturas Impactadas entre Fundão e Candonga}

\section{1 - Recuperação das Escolas e Reintegração da Comunidade Escolar}

16 - Retomada das Atividades Aquícolas e Pesqueiras

\section{7 - Retomada das Atividades Agropecuárias}

18 - Desenvolvimento e Diversificação Econômica

19 - Programa de Recuperação de Micro e Pequenos Negócios

23 - Manejo de Rejeitos

24 - Contenção de Rejeitos e Tratamento de Rios

26 - Programa de Recuperação de Áreas de Preservação Permanente (APPs) e Recargas Hídricas

27 - Programa de Recuperação de Nascentes

31 - Coleta e Tratamento de Esgoto e Destinação de Resíduos Sólidos

32 - Melhoria dos Sistemas de Abastecimento de Água

33 - Educação Ambiental para Revitalização da Bacia do Rio Doce

\section{EFICIÊNCIA ENERGÉTICA (EE)}

\section{ENERGIA RENOVÁVEL (ER)}

- Usar menos energia na construção, por meio de processos e máquinas com maior EE

- Considerar a EE nos projetos das casas que serão construídas

- Usar menos energia na construção, por meio de processos e máquinas com maior $\mathrm{EE}$

- Usar menos energia na construção, por meio de processos e máquinas com maior $\mathrm{EE}$

- Considerar a EE nos projetos das casas que serão construídas

- Usar menos energia na construção, por meio de processos e máquinas com maior $\mathrm{EE}$

- Considerar a EE nos projetos das casas que serão construídas

- Considerar a EE nos projetos

- Considerar a EE nos projetos

- Considerar a EE nos projetos

- Considerar a EE nos projetos

- Considerar a EE nos projetos

- Usar menos energia na construção, por meio de processos e máquinas com maior $\mathrm{EE}$

- Usar menos energia na construção, por meio de processos e máquinas com maior EE

- Usar menos energia na construção, por meio de processos e máquinas com maior $\mathrm{EE}$

- Considerar usar sistemas de tratamento inovadores e com maior $\mathrm{EE}$

- Considerar usar sistemas de tratamento inovadores e com maior EE

- Incluir EE nos currículos
- Considerar:

- Instalar energia solar nas edificações

- Instalar usinas de ER para a geração de energia comunitária, tais como energia eólica, energia solar e usinas de geração de energia a partir de resíduos sólidos (waste-to-energy)Instalar energia solar nas edificações

- Considerar:

- Instalar energia solar na UHE Risoleta Neves

- Mudar o combustível usado no transporte interno e externo (por exemplo, biodiesel ou etanol)

- Considerar:

- Instalar energia solar nas edificações - Instalar usinas de ER para a geração de energia comunitária, tais como energia eólica, energia solar e usinas de geração waste-to-energy

- Considerar o uso de energia solar nas escolas que serão recuperadas

- Considerar o uso de energia solar nos locais

- Considerar o uso de energia solar e biodigestores waste-to-energy nos locais

- Substituir o combustível no transporte

- Substituir o combustível no transporte

- Considerar o uso de energia solar nos locais

- Substituir o combustível no transporte

- Substituir o combustível no transporte

- Substituir o combustível no transporte

- Considerar a geração de energia solar e waste-to-energy

- Considerar o uso de energia solar

- Incluir EE nos currículos 


\section{4 | Caminhos alternativos}

\subsection{Modalidades de financiamento para a ação climática}

Em 2018 e 2019, as iniciativas de precificação de carbono se multiplicaram ao redor do planeta e os sistemas que já existiam foram reforçados. ${ }^{17}$ Os governos angariaram aproximadamente US\$ 44 bilhões em receitas de precificação de carbono em 2018 (World Bank, 2019). Algumas coalizões industriais recentemente propuseram uma estrutura nacional de precificação de carbono para o Brasil, visando estimular esse tipo de investimento (CEBDS \& CPL, 2018). Essas iniciativas governamentais, em meio a outras oportunidades de redução das emissões de GEE, variam desde a tributação do carbono até sistemas de comercialização de emissões, gerando modalidades de financiamento de carbono que incluem a compensação de emissões em outros setores por meio de projetos de sequestro de carbono, energias renováveis e eficiência energética.

Um exemplo é o setor de mineração, que gera emissões consideráveis que podem ser sujeitas a mecanismos governamentais de precificação de carbono. Essas indústrias poderiam, em parte, compensar suas emissões por meio de programas de florestamento e iniciativas ligadas à energia limpa, investindo em projetos no Brasil ou em outros países. Se o projeto for desenvolvido com parceiros locais, as receitas desse investimento poderão ser reinvestidas nas comunidades locais, em capacitação e ações preventivas para adaptação à mudança climática, além de novos esforços de mitigação. Em nível global, a NFCCC criou o Green Climate Fund em 2019 como fonte de financiamento da adaptação à mudança climática pelo setor público e privado em países em desenvolvimento (Green Climate Fund, s.d.). Também foram criados fundos de investimentos verdes (Sullivan, 2020).

O financiamento de carbono continua tendo seu papel nos esforços de restauração florestal, que, após um declínio na escala e nos preços dos mercados de carbono, estão novamente sendo fortalecidos com a recente implementação de mecanismos de precificação de carbono em diversos países. Uma das iniciativas que podem se beneficiar dos mercados de carbono é a criação de sistemas de Pagamento por Serviços Ambientais (PSA), um mecanismo que também foi adotado pela Renova em suas atividades de restauração com proprietários privados para compensá-los por seus esforços de conservação e restauração de florestas nas margens de rios. No Brasil, a compensação das emissões de GEE por meio do financiamento de esforços de restauração natural de florestas é incentivada pela legislação vigente e apresenta oportunidades de restauração de áreas degradadas. ${ }^{18}$

O sucesso da restauração e regeneração da vegetação nativa dependerá da disposição dos proprietários de terra em dedicar parte de suas terras a esse objetivo. Para incentivar essa ação, a Câmara Técnica de Restauração Florestal e Produção de Água (CT-Flor) do CIF e a Fundação Renova criaram uma iniciativa de PSA que visa apoiar e estimular a adesão dos roprietários rurais mediante um incentivo ao produtor no valor de até $R \$ 252^{19}$ por hectare

17 De acordo com a Convenção-Quadro das Nações Unidas sobre Mudança do Clima (UNFCCC), o preço do carbono reduz as emissões de GEE através da cobrança de uma taxa de emissão e/ou do incentivo à redução das emissões. Com isso, gera-se um sinal de preço que altera os padrões de consumo e investimento, compatibilizando o desenvolvimento econômico com a proteção climática. Para mais informações, ver https://unfccc.int/about-us/regional-collaboration-centres/the-ci-aca-initiative/ about-carbon-pricing\#eq-1.

18 O novo Código Florestal (Lei 12.651/2012) prevê a permuta de áreas protegidas na forma de Reservas Legais entre proprietários de terras. O comércio de carbono também é permitido no arcabouço do Plano Nacional sobre Mudança do Clima. 
por ano. ${ }^{20}$ Vale destacar, no entanto, que parte importante do sucesso das abordagens de PSA é a continuidade dos pagamentos para garantir a proteção e o monitoramento dos estoques de carbono e/ou água e outros serviços ambientais em cada local, além do direcionamento dos pagamentos de modo a priorizar as áreas onde trarão o maior benefício social e ambiental (Pagiola et al., 2012). ${ }^{21}$ Nesse sentido, a Renova poderia identificar oportunidades de compensação de outros setores e criar mecanismos de financiamento que garantam fundos de longo prazo para o PSA.

\subsection{Soluções baseadas na Natureza para a adaptação climática}

A UICN define as SbN como "ações para proteger, administrar de maneira sustentável e restaurar ecossistemas naturais ou modificados, que respondam aos desafios da sociedade de maneira efetiva e adaptativa, proporcionando, simultaneamente, o bem-estar humano e os benefícios da biodiversidade" (Cohen-Shacham et al., 2016). Ou seja, o conceito de SbN vai além do mero usufruto de serviços ecossistêmicos para, de maneira proativa, aumentar a capacidade dos ecossistemas de fornecer serviços essenciais ao bem-estar humano. As SbN são estruturadas para acomodar aplicações específicas da abordagem ecossistêmica, quando a gestão ou restauração das funções do ecossistema pode ter um papel crítico no enfrentamento aos desafios da sociedade, como a adaptação à mudança climática.

No século passado, a humanidade fez grandes avanços na substituição de infraestruturas naturais - como florestas, eficazes no fornecimento de água limpa - por infraestruturas criadas pelo homem, como barragens que armazenam água e sedimentos e diques contra enchentes. Na maioria das vezes, essas estruturas artificiais não foram projetadas para suportar os efeitos da mudança climática ou de fortes tempestades. Cada vez mais, a conclusão é de que a manutenção dessas estruturas e instalações aumenta o risco para as sociedades humanas. As $\mathrm{SbN}$ procuram sanar esses riscos - em alguns casos, renaturalizando os cursos d'água e removendo obstáculos artificiais à vazão da água e outros serviços ecossistêmicos críticos.

O papel das SbN em apoio à adaptação à mudança climática deve, portanto, levar em conta o potencial de oferecer um "pacote" de serviços ecossistêmicos, incluindo, por exemplo, o acúmulo de estoques de carbono, a conservação da biodiversidade e o abastecimento de água. Medidas semelhantes adotadas em outros países, que podem servir de modelo para as ações da Renova, são descritas em estudos de caso avaliados por meio da Estrutura de SbN da UICN (Andrade Pérez et al., 2010; CohenShacham et al., 2019).

Algumas das abordagens e dos resultados dos programas ambientais do TTAC podem estar associados a metas e objetivos relacionados às $\mathrm{SbN}$, como a recuperação de APPs (programa 26) e nascentes (programa 27), bem como a consolidação de unidades de conservação (programa 39). De fato, o objetivo inspirado pelo TTAC de restaurar 47.850 hectares de floresta nativa pode ser insuficiente para satisfazer as muitas demandas por serviços ecossistêmicos em toda a Bacia do Rio Doce, mas sua eficácia pode ser reforçada por intervenções estratégicas na paisagem e pela adoção de práticas e abordagens complementares de SbN.

Outro exemplo de abordagem de SbN que a Renova já utiliza no manejo de rejeitos (programa 23) é a renaturalização de cursos d'água em partes da bacia hidrográfica de Gualaxo do Norte. ${ }^{22}$

20 Para mais informações, ver https://www.fundacaorenova.org/noticia/pagamento-por-servicos-ambientais-psa-vai-remunerar-osproprietarios-rurais-que-promoverem-acoes-de-recuperacao-ambiental/

21 Ver em May et al. (2019) a descrição dos programas de PSA em Minas Gerais e no Espírito Santo que contribuíram para o desenho dos programas de PSA do TTAC.

22 Ver https://www.fundacaorenova.org/dadosdareparacao/terra-e-agua/ 


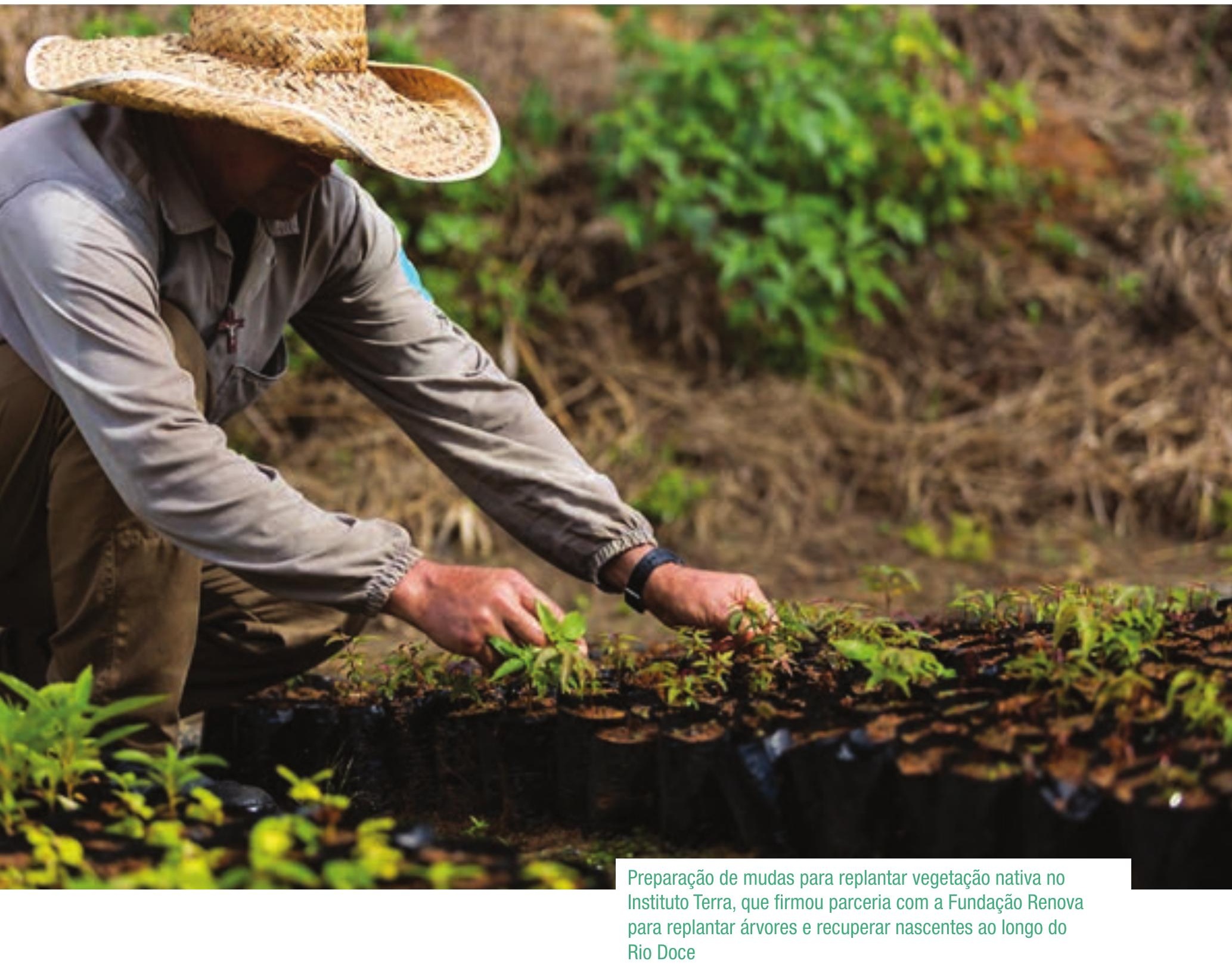

Foto: NITRO 


\section{5 | Conclusões e recomendações}

Com base nos dados e nas informações apresentados neste relatório, o Painel do Rio Doce chegou às seguintes conclusões:

- Os modelos climáticos disponíveis apontam para o aumento da temperatura média da superfície e alterações nos regimes de chuva em toda a Bacia do Rio Doce a longo prazo. No litoral, são previstas inundações causadas pela elevação do nível do mar e erosão costeira, embora ainda não haja previsões detalhadas sobre a mudança climática no Espírito Santo.

- Os impactos do rompimento da Barragem de Fundão contribuem para o aumento da vulnerabilidade do território, exacerbando a exposição e a sensibilidade a fatores de risco associados à adaptação à mudança climática, principalmente em relação aos meios de subsistência e à saúde humana e do ecossistema.

- Mais da metade dos 42 programas do TTAC apresenta objetivos ou resultados potencialmente ameaçados ou comprometidos pelos efeitos previstos da mudança climática, principalmente aqueles associados à escassez de recursos hídricos ou a eventos extremos de chuva. Embora a Renova tenha tomado as medidas adequadas para evitar a vulnerabilidade climática em muitos desses programas, alguns ainda correm risco dadas as previsões de mudança climática.

- Vários programas do TTAC e sua manutenção a longo prazo podem contribuir para a mitigação das emissões de GEE por meio da adoção de tecnologias adequadas de geração e uso de energia.
- A proliferação de mecanismos globais de precificação de carbono traz várias oportunidades de acordos de financiamento em prol de ações climáticas.

- A Renova já implementa Soluções baseadas na Natureza ( $\mathrm{SbN}$ ) que podem contribuir para a adaptação climática, a restauração florestal e a redução de emissões de GEE. Essas SbN podem também se beneficiar do financiamento de carbono e ser aprimoradas para garantir implementação a longo prazo e investimentos em capacitação e ações preventivas de adaptação à mudança climática, bem como outros esforços de mitigação.

À luz dessas conclusões e com base nas recomendações de seu primeiro relatório temático, o Painel recomenda que a Fundação Renova responda aos possíveis efeitos de longo prazo da mudança climática que ameaçam a eficácia e sustentabilidade dos resultados de seus programas e, dessa forma, contribua para a transição para uma economia de baixo carbono na bacia como parte de seu legado.

Para atingir esses objetivos, o Painel urge a Renova a cooperar plenamente com suas partes interessadas e instituições parceiras, incluindo o Ministério Público e o poder judiciário, para integrar considerações sobre a mudança climática em seus programas e fortalecer as capacidades locais e estaduais para adaptação à mudança climática.

A sustentabilidade dos programas do TTAC depende, em última análise, de uma resposta adequada à mudança climática iminente. Mais especificamente, o Painel faz as seguintes recomendações: 


\section{Recomendação 1}

\section{Iniciar um diálogo em direção ao desenvolvimento de um Plano de Ação Climática para a Bacia do Rio Doce}

Reconhecendo que a Renova não pode ser responsabilizada integralmente por fatores associados à mitigação e adaptação à mudança climática na Bacia do Rio Doce, o Painel recomenda que a Renova organize um grupo interinstitucional de trabalho. Com representantes dos dois governos estaduais, representantes setoriais, Ministério Público e poder judiciário, o grupo consideraria primeiro as ameaças que a mudança climática potencialmente representa ao sucesso dos resultados dos programas do TTAC; posteriormente, desenvolveria um plano de ação climática para a bacia. Inicialmente, o grupo de trabalho se concentraria nas medidas de adaptação, na definição de projetos de redução de emissões de GEE e na identificação de oportunidades financeiras associadas à ação climática na bacia.

A organização de um grupo de trabalho dessa natureza poderia ficar sob a coordenação do Comitê da Bacia Hidrográfica do Rio Doce. Reconhecendo a necessidade de levar em consideração a Bacia do Rio Doce como um todo, dentro de um sistema fonte-mar, o Painel recomenda que seja adotada uma estratégia unificada de bacia hidrográfica para avaliação e adaptação aos efeitos da mudança climática. 


\title{
Recomendação 2
}

\author{
Propor que o CIF e outras entidades \\ integrem a perspectiva da mudança \\ climática em uma revisão oportuna \\ dos programas relevantes do TTAC
}

Espera-se que o envolvimento dos membros do CIF e das entidades participantes em uma revisão cuidadosa dos programas do TTAC e das interações entre eles, a partir da perspectiva da mudança climática, permita aumentar as sinergias entre os programas. Isso ajudará a garantir resultados de longo prazo para a sociedade e para a natureza na Bacia do Rio Doce com a implementação desses programas, promovendo:

- maior resiliência a eventos climáticos extremos a longo prazo nas ações de restauração;

- identificação de projetos de redução de emissões de GEE que possam ser implementados além dos já existentes;

- adoção de objetivos estratégicos em matéria de ação climática, com base na discussão das possibilidades, na priorização das opções e na definição das metas na implementação dos programas;

- desenvolvimento de inventários de emissões e sequestros de carbono decorrentes das ações de restauração, evidenciando o papel proativo do esforço geral de restauração em apoio à prontidão das medidas de adaptação à mudança climática e aos eventos extremos esperados;

- avaliação da pegada de carbono das operações empreendidas pela Renova, incluindo emissões e sequestros de carbono nos ecossistemas regionais e opções tecnológicas de baixo carbono. Como parte da avaliação das ameaças e oportunidades da mudança climática relativas às ações de restauração, a contabilidade de carbono possibilitaria uma identificação mais estratégica daquelas ações com efeitos mais expressivos de mitigação climática; e

- identificação de possíveis oportunidades financeiras para programas já em andamento, como o PSA e outros instrumentos. 


\title{
Recomendação 3
}

\author{
Adotar Soluções baseadas na Natureza ao \\ considerar alternativas tecnológicas de \\ remediação, restauração e compensação
}

Deve ser adotada uma abordagem de SbN para orientar os princípios de restauração das funções e dos serviços ecossistêmicos, incluindo o sequestro de carbono. Foi o que aconteceu nas ações de renaturalização de cursos d'água executadas pela Renova em partes da bacia hidrográfica do rio Gualaxo do Norte. Essa abordagem pode se estender com a continuação de $\mathrm{SbN}$, em vez de abordagens de infraestrutura que fazem uso intensivo de terraplanagem e construção com uso pesado de combustíveis fósseis (por exemplo, a remoção de rejeitos).

A utilização de processos naturais como base para priorizar as intervenções de restauração representa uma forma de garantir maior resiliência aos extremos climáticos (devido à maior diversidade de ecossistemas naturais), que também pode ser bem menos onerosa do que as abordagens atreladas a investimentos de capital material. $\mathrm{Na}$ adoção de uma abordagem de SbN, é necessário comparar essas opções de restauração com as baseadas em técnicas convencionais para determinar seus custos e benefícios relativos, bem como a eficácia esperada na sua resposta a eventos climáticos extremos a longo prazo. 


\title{
Recomendação 4
}

\author{
Convidar governos estaduais e locais \\ a desenvolver suas capacidades e \\ empreender ações preparatórias para \\ se adaptarem à mudança climática
}

A capacitação nos níveis estadual e local é a chave do sucesso na preparação para eventos climáticos extremos. Atualmente, os processos de planejamento e avaliação de vulnerabilidades e impactos climáticos têm sido realizados em Minas Gerais nos níveis estadual e microrregional, mas falta uma avaliação e um plano em paralelo no Espírito Santo. Nos dois casos, esses estudos e instrumentos devem ter por base um processo participativo e estar sujeitos a avaliação e revisão periódicas para informar as autoridades estaduais e locais e outras partes interessadas relevantes, além de servir de base para ações climáticas.

Exemplos de medidas de adaptação incluem o zoneamento restritivo de áreas de risco devido à instabilidade de encostas, alertas de emergência e rotas de fuga. Em alguns casos, essas ações são semelhantes às necessárias em resposta ao rompimento da Barragem de Fundão. No entanto, a capacitação para fins de adaptação climática precisará considerar os piores cenários de extremos climáticos a longo prazo e se preparar para essas variações. 


\section{Referências}

Albino, J., Paiva, D.S. e Machado, G.M. (2001). 'Geomorfologia, tipologia, vulnerabilidade erosiva e ocupação urbana das praias do litoral do Espírito Santo, Brasil'. Geografares 2: 63-69. Disponível em: https://docplayer.com.br/67296858-Geomorfologiatipologia-espirito-santo-brasil-vulnerabilidade-erosivae-ocupacao-urbana-das-praias-do-litoral-do.html

Alonso, L.B.N., Barbosa, F.A.R., Brito, M.C.W., May, P., Maroun, C., Sánchez, L.E. e Kakabadse, Y. (2020). Interconexões entre a saúde humana e ecossistêmica: Uma abordagem integrativa para a Bacia do Rio Doce após o rompimento da Barragem de Fundão. (Questões em Foco, $\mathrm{n}^{\circ} 5$ do Painel do Rio Doce). Gland, Suíça: UICN. Disponível em: https://www.iucn. org/riodocepanel/issue-paper-5-PT

Andrade Pérez, A., Hererra Fernández, B., Cazzolla Gatti, R. (eds.) (2010). Building Resilience to Climate Change: Ecosystem-Based Adaptation and Lessons from the Field. Ecosystem Management Series No. 9. Gland, Suíça: UICN. Disponível em: https://portals. iucn.org/library/node/9680

Beck, H. E., Zimmermann, N.E., McVicar, T.R., Vergopolan, N., Berg, A. e Wood, E.F. (2018). 'Present and future Köppen-Geiger climate classification mapsat 1-km resolution. Scientific Data. 5:180214. Disponível em: https://doi.org/10.1038/sdata.2018.214

Brasil (2015). Pretendida Contribuição Nacionalmente Determinada para consecução do objetivo da Convenção-Quadro das Nações Unidas sobre Mudança do Clima. Disponível em: https://www.mma. gov.br/images/arquivo/80108/BRASIL\%20iNDC\%20 portugues\%20FINAL.pdf

Cohen-Shacham, E., Andrade, A., Dalton, J. Dudley, N., Jones, M., Kumar, C., Maginnis, S., Maynard, S., Nelson, C.R., Renaud, F., Welling, R. e Walters, G. (2019). 'Core principles for successfully implementing and upscaling Nature-based Solutions'. Environmental
Science and Policy 98: 20-29. Disponível em: https:// serval.unil.ch/resource/serval:BIB_92B5E056096D. P001/REF

Cohen-Shacham, E., Walters, G., Janzen, C. e Maginnis, S. (eds.) (2016). Nature-based Solutions to address global societal challenges. Gland, Switzerland: IUCN. Disponível em: https://doi.org/10.2305/IUCN. CH.2016.13.en

Conselho Empresarial Brasileiro para Desenvolvimento Sustentável (CEBDS) e Coalizão da Liderança do Preço do Carbono (CPLC) (2018). Precificação do carbono na indústria brasileira: Uma iniciativa estratégica. Rio de Janeiro: CEBDS e CPLC. Disponível em: https://static1.squarespace.com/ static/54ff9c5ce4b0a53decccfb4c/t/5b9285a3 032be49d6859647b/1536329124475/CEBDS PrecificacaoCarbono_Ingles_2707.pdf

Crippa, M., Oreggioni, G., Guizzardi, D., Muntean, M., Schaaf, E., Lo Vullo, E., Solazzo, E., Monforti-Ferrario, F., Olivier, J.G.J., Vignati, E. (2019). Fossil $\mathrm{CO}_{2}$ and GHG emissions of all world countries. 2019 Report. Luxembourg: EUR 29849 EN, Publications Office of the European Union. Disponível em: http://dx.doi. org/10.2760/687800

Cupolillo, F. (2008). Diagnóstico Hidroclimatológico da Bacia do Rio Doce. [Tese de Doutorado, Universidade Federal de Minas Gerais]. Disponível em: http://hdl. handle.net/1843/MPBB-7F8NTB

Cupolillo, F., de Abreu, M.L. e Vianello, R.L. (2008). 'Climatologia da bacia do rio Doce e sua relação com a topografia local'. Revista Geografias 4(1): 45-60. Disponível em: https://periodicos.ufmg.br/index.php/ geografias/article/download/13251/10483

Dominguez, J.M.L., Martin, L. e Bittencourt, A.C.S.P. (1987). 'Sea-level history and Quaternary evolution of river mouth-associated beach-ridge plains along 
the east-southeast Brazilian coast: a summary'. In: D. Nummedal, O.H. Pilkey \& J.D. Howard (eds.). Sea-Level Fluctuations and Coastal Evolution. SEPM Society for Sedimentary Geology 41: 115-127. Disponível em: https://doi.org/10.2110/pec.87.41.0115

Eurostat. (s.d.). Glossary: global-warming potential (GWP). Disponível em: https://ec.europa.eu/eurostat/ statistics-explained/index.php/Glossary:Globalwarming_potential_\%28GWP\%29

Fundação Estadual de Meio Ambiente (FEAM) (2011). Avaliação de impactos de mudanças climáticas sobre a economia mineira: relatório resumo. Belo Horizonte. Disponível em: https://www.cepal.org/sites/default/ files/events/files/documento_edson_dominguez_ cedeplar.pdf

(2014). Estudo de vulnerabilidade regional às mudanças climáticas. Belo Horizonte. Disponível em: http://www.feam.br/images/stories/Estudos/pemc_ vulnerabilidade_regional\%2021022014.pdf

(2015). Plano de Energia e Mudanças Climáticas do Estado de Minas Gerais. Resumo Executivo. Belo Horizonte. Disponível em: http://www.feam.br/images/ stories/2015/ENERGIA_M_CILMATICAS/010615pemc_ sumario_executivo_capa_nova_ficha_catalografica.pdf

Fundação Renova, Universidade Federal de Minas Gerais (UFMG), \& Universidade Federal de Viçosa (UFV) (2018). Metodologia de priorização: Definição de critérios de áreas para recuperação ambiental na Bacia do Rio Doce. Disponível em: https://www. fundacaorenova.org/wp-content/uploads/2020/02/ metodolgiadepriorizarecuperacaoambientalufvufmg.pdf

Goldstein, A., Turner, W.R., Spawn, S.A., Teixeira, A.K.J., Cook-Patton, S., Fargione, J., Gibbs, H.K., Griscom, B., Hewson, J.H., Howard, J.F., Ledezma, J.C., Page, S., Koh, L.P., Rockström, J., Sanderman, J. e Hole, D.G. (2020). 'Protecting irrecoverable carbon in Earth's ecosystems'. Nature Climate Change 10: 287-295. Disponível em: https://doi.org/10.1038/ s41558-020-0738-8
Green Climate Fund (2019). Raising Ambition, Empowering Action. Report on the progress of the Green Climate Fund during its initial resource mobilization period (January 2015 to July 2019). Incheon, Republic of Korea. Disponível em: https://www. greenclimate.fund/sites/default/files/document/raisingambition-empowering-action-report-progress-gcf-1.pdf

(s.d.). GCF in Brief: Adaptation Planning. Catalysing action and finance for country adaptation priorities. Incheon, Republic of Korea. Disponível em: https://www.greenclimate.fund/sites/default/files/ document/gcf-brief-adaptation-planning_0.pdf

Intergovernmental Panel on Climate Change (IPCC) (2007a). Climate Change 2007: Impacts, Adaptation and Vulnerability. Contribution of Working Group II to the Fourth Assessment Report of the Intergovernmental Panel on Climate Change. M.L. Parry, O.F. Canziani, J.P. Palutikof, P.J. van der Linden \& C.E. Hanson (eds.). Cambridge, UK: Cambridge University Press. Disponível em: https://www.ipcc.ch/ site/assets/uploads/2018/03/ar4_wg2_full_report.pdf

(2007b). Climate Change 2007: The physical science basis. Contribution of Working Group I to the Fourth Assessment Report of the Intergovernmental Panel on Climate Change. S. Solomon, D. Qin, M. Manning, Z. Chen, M. Marquis, K. Averyt, M.M.B. Tignor and H.L. Miller (eds.). Cambridge, United Kingdom and New York, NY, USA: Cambridge University Press. Disponível em: https://www.ipcc.ch/ report/ar4/wg1/

(2012). 'Glossary of terms'. In: Managing the Risks of Extreme Events and Disasters to Advance Climate Change Adaptation [Field, C.B., V. Barros, T.F. Stocker, D. Qin, D.J. Dokken, K.L. Ebi, M.D. Mastrandrea, K.J. Mach, G.-K. Plattner, S.K. Allen,M. Tignor, and P.M. Midgley (eds.)]. A Special Report of Working Groups I and II of the Intergovernmental Panel on Climate Change (IPCC). Cambridge University Press, Cambridge, UK, and New York, NY, USA, pp. 555-564. Disponível em: https://archive.ipcc.ch/pdf/ special-reports/srex/SREX-Annex_Glossary.pdf 
(2014a). Climate Change 2014: Synthesis

Report. Contribution of Working Groups I, II and III to the Fifth Assessment Report of the Intergovernmental Panel on Climate Change (Core Writing Team, R.K. Pachauri and L.A. Meyer, orgs.). Geneva, Switzerland: IPCC. Disponível em: https://www.ipcc.ch/report/ar5/ syr/

(2014b). 'Central and South America'. In: Climate Change 2014 - Impacts, Adaptation and Vulnerability: Part B: Regional Aspects: Working Group II Contribution to the IPCC Fifth Assessment Report (pp. 1499-1566). Cambridge: Cambridge University Press. Disponível em: https://doi. org/10.1017/CBO9781107415386.007

(2018a). 'Annex I: Glossary' [Matthews, J.B.R. (ed.)]. In: Global Warming of $1.5^{\circ} \mathrm{C}$. An IPCC Special Report on the impacts of global warming of $1.5^{\circ} \mathrm{C}$ above pre-industrial levels and related global greenhouse gas emission pathways, in the context of strengthening the global response to the threat of climate change, sustainable development, and efforts to eradicate poverty [Masson-Delmotte, V., P. Zhai, H.O. Pörtner, D. Roberts, J. Skea, P.R. Shukla, A. Pirani, W. Moufouma-Okia, C. Péan, R. Pidcock, S. Connors, J.B.R. Matthews, Y. Chen, X. Zhou, M.I. Gomis, E. Lonnoy, T. Maycock, M. Tignor, and T. Waterfield (eds.)]. In Press. Disponível em: https://www.ipcc.ch/ sr15/ and https://www.ipcc.ch/site/assets/uploads/ sites/2/2019/06/SR15_Annexl_Glossary.pdf

(2018b). 'Summary for policymakers'. In: Global warming of $1.5^{\circ} \mathrm{C}-$ An IPCC Special Report on the impacts of global warming of $1.5^{\circ} \mathrm{C}$ above preindustrial levels and related global greenhouse gas emission pathways, in the context of strengthening the global response to the threat of climate change, sustainable development, and efforts to eradicate poverty. V. Masson-Delmotte, P. Zhai, H.-O. Pörtner, D. Roberts, J. Skea, P.R. Shukla, A. Pirani, W. Moufouma-Okia, C. Péan, R. Pidcock, S. Connors, J.B.R. Matthews, Y. Chen, X. Zhou, M.I. Gomis, E. Lonnoy, T. Maycock, M. Tignor, and T. Waterfield (eds.). Geneva, Switzerland: World Meteorological
Organization. Disponível em: https://www.ipcc.ch/site/ assets/uploads/sites/2/2019/05/SR15_SPM_version_ report_LR.pdf

International Union for Conservation of Nature (IUCN). (2011). IUCN Glossary of Definitions. IUCN website. Disponível em: https://www.iucn.org/resources/ publications/publishing-iucn

(2016). 'Defining Nature-based Solutions'. World Conservation Congress 2016 Resolution 069EN. Disponível em: https://portals.iucn.org/library/ node/46486

Lee, S.-H. e Lee, S.-Y. (2018). 'An analysis of the effects of climate change policy, stakeholder pressure, and corporate carbon management on carbon efficiency on the Korean petrochemical industry'. Sustainability, 10: 4420. Disponível em: https://doi. org/10.3390/su10124420

Lorena, R.B. et al. (2013). Inventário de Emissão de Gases de Efeito Estufa do Estado do Espírito Santo: Sumário Executivo. Espírito Santo. 22 p. Disponível em: https://cetesb.sp.gov.br/inventario-geesp/2013/10/20/inventario-de-emissao-de-gases-deefeito-estufa-do-estado-do-espirito-santo-sumarioexecutivo/

Margulis, S. (2017). Guia de adaptação a mudanças do clima para entes federativos. Brasília: WWF/ ICLEl. Disponível em: https://d3nehc6yl9qzo4. cloudfront.net/downloads/guia_adaptacao_wwf_iclei_ revfinal_01dez_2.pdf

Matthews, R.B. e van Noordwijk, M. (2014). 'From euphoria to reality on efforts to reduce emissions from deforestation and forest degradation (REDD+)'. Mitigation and Adaptation Strategies for Global Change, 19(6): 615-620. Disponível em: https://doi. org/10.1007/s11027-014-9577-0

May, P., Alonso, L., Barbosa, F.A.R., Brito, M.C.W., Laureano, F.V., Sánchez, L.E. e Kakabadse, Y. (2019). Alternativas para meios de vida em paisagens rurais da 
Bacia do Rio Doce após o rompimento da Barragem de Fundão. Criando oportunidades para o futuro. Painel do Rio Doce Questões em Foco №1. Gland, Suíça: UICN. Disponível em: https://www.iucn.org/ riodocepanel/issue-paper-1-PT

Muehe, D. (2010). 'Brazilian coastal vulnerability to climate change'. Pan-American Journal of Aquatic Sciences, 5(2): 173-183. Disponível em: https:// panamjas.org/pdf_artigos/PANAMJAS_5(2)_173-183. pdf

Myhre, G., Shindell, D., Bréon, F.-M., Collins, W., Fuglestvedt, J., Huang, J. Koch, D., Lamarque, J.-F., Lee, D., Mendoza, B., Nakajima, T., Robock, A., Stephens, G., Takemura, T. and Zhang, H. (2013). 'Anthropogenic and Natural Radiative Forcing'. In: Climate Change 2013: The Physical Science Basis. Contribution of Working Group I to the Fifth Assessment Report of the Intergovernmental Panel on Climate Change [Stocker, T.F., D. Qin, G.-K. Plattner, M. Tignor, S.K. Allen, J. Boschung, A. Nauels, Y. Xia, V. Bex and P.M. Midgley (eds.)]. Cambridge University Press, Cambridge, United Kingdom and New York, NY, USA. Disponível em: https://www.ipcc.ch/site/assets/ uploads/2018/02/WG1AR5_Chapter08_FINAL.pdf

Nimer, E. (1989). Climatologia do Brasil. Rio de Janeiro: IBGE. Disponível em: https://biblioteca.ibge. gov. br/biblioteca-catalogo id=281099\&view=detalhes

Pagiola, S., Carrascosa, H. e Taffarello, D. (eds.) (2012). Experiências de pagamentos por serviços ambientais no Brasil. Secretaria do Meio Ambiente de São Paulo. Disponível em: http://documents. worldbank.org/curated/en/548371468021548454/ pdf/864940WPOP088000PORTUGUESEOPSAlivro.pdf

Phillips, D. (2019). 'Climate crisis blamed for rains and floods that have killed 150 in Brazil'. The Guardian (13 March 2020). Disponível em: https://www. theguardian.com/environment/2020/mar/13/climatecrisis-blamed-for-rains-and-floods-that-have-killed150-in-brazil
Pirovani, D.B. (2014). Cenários de mudanças climáticas e impacto no zoneamento agroclimático de espécies florestais no estado do Espírito Santo. [Teste de doutorado, Universidade Federal do Espírito Santo]. Disponível em: http://repositorio. ufes.br/bitstream/10/4877/1/tese_7155_Daiani\%20 Bernardo\%20Pirovani.pdf

Piveta, M. (2018). 'José Antonio Marengo Orsini: A time of uncertainty'. Interview. Pesquisa FAPESP 273. Disponível em: https://revistapesquisa.fapesp.br/ en/2019/06/18/jose-antonio-marengo-orsini-a-time-ofuncertainty/

Presidência da República do Brasil (2012). Lei $n^{\circ}$ 12.651, de 25 de maio de 2012 . Código Florestal. Disponível em: http://www.planalto.gov.br/ccivil_03/_ Ato2011-2014/2012/Lei/L12651compilado.htm

Queiroz, H.M., Nóbrega, G.N., Ferreira, T.O., Almeida, L.S., Romero, L.B., Santaella, S.T., Bernardino, A.T. e Otero, X.L. (2018). 'The Samarco mine tailing disaster: A possible time-bomb for heavy metals contamination?'. Science of the Total Environment 637-638: 498-506. Disponível em: https://doi. org/10.1016/j.scitotenv.2018.04.370

Renova Foundation, Federal University of Minas Gerais (UFMG) and Federal University of Viçosa (UFV) (2018). Metodologia de priorização.

Definição de criterios de áreas para recuperação ambiental na Bacia do Rio Doce. Rio de Janeiro: Renova Foundation. Disponível em: https://www. fundacaorenova.org/wp-content/uploads/2020/02/ metodolgiadepriorizarecuperacaoambientalufvufmg. pdf

Ronquim, C.C., Silva, R.F.B., de Figueiredo, E.F.B., Bordonal, R.O., Teixeira, A.H.C., Cochasrk, T.S.D. e Leivas, J.L. (2016). 'Carbon sequestration associated to the land-use and land-cover changes in the forestry sector in Southern Brazil'. In: Remote Sensing for Agriculture, Ecosystems, and Hydrology XVIII. Neale, C.M.U., Maltese, A. (eds.). Disponível em: https://doi. org/10.1117/12.2242094 
Rotmans, J. e Loorbach, D. (2009). 'Complexity and transition management'. Journal of Industrial Ecology 13(2): 184-19. Disponível em: https://doi.org/10.1111/ j.1530-9290.2009.00116.x

Sánchez, L.E., Alger, K., Alonso, L., Barbosa, F., Brito, M.C.W., Laureano, F.V., May, P., Roeser, H., Kakabadse, Y. (2018). Os impactos do rompimento da Barragem de Fundão. O caminho para uma mitigaçao sustentável e resiliente. Relatório Temático Nㅡ1 do Painel do Rio Doce. Gland, Suíça: UICN. Disponível em: https://doi.org/10.2305/IUCN.CH.2018.18.pt

Scherr, S.J., Shames. S. e Friedman, R. (2012). 'From climate-smart agriculture to climate-smart landscapes'. Agriculture and Food Security, 1:12. Disponível em: https://doi.org/10.1186/2048-7010-112

Sistema de Estimativa de Emissões de Gases de Efeito Estufa (SEEG) (s.d.). Emissões totais 2018. Disponível em: http://plataforma.seeg.eco.br/total_ emission\#

Sullivan, P. (2020). 'A Call for Investors to Put Their Money Toward a Green Future'. New York Times (24 January 2020) [sítio web]. Disponível em: https:// www.nytimes.com/2020/01/24/business/greeninvestments-climate-change.html

Tessler, M. (2008). 'Potencial de Risco Natural'. In: Zamboni, A. e Nicolodi, J. L. (eds.). Macrodiagnóstico da Zona Costeira e Marinha do Brasil, pp. 93-120. Brasília: Ministério do Meio Ambiente.
United Nations Framework Convention on Climate Change (UNFCCC) (s.d.). Glossary of climate change acronyms and terms. UNFCCC website. Disponível em: https://unfccc.int/process-and-meetings/theconvention/glossary-of-climate-change-acronymsand-terms\#c

Voosen, P. (2018). 'The Earth Machine'. Science, 361(6400): 344-347. Disponível em: https://doi. org/10.1126/science.361.6400.344

Watson, J.E.M., Rao, M., Ai-Li, K. e Yan, X. (2012). 'Climate Change Adaptation Planning for Biodiversity Conservation: A Review'. Advances in Climate Change Research, 3(1): 1-11. Disponível em: https://doi. org/10.3724/SP.J.1248.2012.00001

World Bank (2019). State and Trends of Carbon Pricing 2019. Washington, DC. License: Creative Commons Attribution CC BY 3.0 IGO. Disponível em: https://doi. org/10.1596/978-1-4648-1435-8

World Business Council for Sustainable Development (WBCSD) and World Resources Institute (WRI) (2004). Greenhouse Gas Protocol. A Corporate Accounting and Reporting Standard. Revised edition. Disponível em: https://ghgprotocol.org/sites/default/files/ standards/ghg-protocol-revised.pdf 


\section{Anexo Definição de termos selecionados}

\begin{abstract}
Acordo de Paris O Acordo de Paris foi adotado em dezembro de 2015 em Paris, na França, na 21 ${ }^{a}$ sessão da Conferência das Partes (COP) da UNFCCC. Adotado por 196 Partes da UNFCCC, o acordo entrou em vigor em 4 de novembro de 2016; em maio de 2018, possuía 195 signatários e havia sido ratificado por 177 Partes. Um de seus objetivos é "manter o aumento da temperatura média global bem abaixo de $2^{\circ} \mathrm{C}$ em relação aos níveis pré-industriais, e envidar esforços para limitar esse aumento da temperatura a $1,5^{\circ} \mathrm{C}$ em relação aos níveis pré-industriais, reconhecendo que isso reduziria significativamente os riscos e os impactos da mudança do clima". Além disso, o acordo visa fortalecer a capacidade dos países de lidar com os impactos da mudança climática. A expectativa é de que o Acordo de Paris seja efetivado na íntegra até 2020 (IPCC, 2018a, p. 555).
\end{abstract}

Adaptação Nos sistemas humanos, significa o processo de adaptação ao clima real ou esperado e seus efeitos, com vista a limitar os danos ou explorar oportunidades benéficas. Nos sistemas naturais, diz respeito ao processo de ajuste ao clima real e seus efeitos. A intervenção humana pode facilitar o ajuste ao clima esperado e seus efeitos (IPCC, 2018a, p. 556).

Antropogênico Resultante de ou produzido por seres humanos (IPCC, 2018a, p. 556).

Aquecimento global $\mathrm{O}$ aumento estimado do valor médio da Temperatura Média Global da Superfície (TMGS) durante 30 anos, ou num período de 30 anos centrado em determinado ano ou década, expresso em relação a níveis pré-industriais, salvo indicação em contrário. Em períodos de 30 anos que abarcam anos passados e futuros, presume-se a continuidade da tendência de aquecimento das décadas anteriores (IPCC, 2018a, p. 550).
Área de preservação permanente (APP) "Área protegida, coberta ou não por vegetação nativa, com a função ambiental de preservar os recursos hídricos, a paisagem, a estabilidade geológica e a biodiversidade, facilitar o fluxo gênico de fauna e flora, proteger o solo e assegurar o bem-estar das populações humanas" (Brasil, 2012).

Área protegida Área de terra e/ou mar especialmente dedicada à proteção da diversidade biológica e dos recursos naturais e culturais associados e administrada por meios legais ou outros meios efetivos.

\section{Business-as-usual (manutenção do status quo)}

A expectativa de que as variáveis nacionais - por exemplo, da economia e do cenário político permaneçam inalteradas por serem a linha de base (IPCC, 2018a, p. 543-544).

\section{Classificação climática de Köppen-Geiger $O$} sistema de Köppen-Geiger categoriza o clima em cinco classes principais e 30 subtipos. A classificação é baseada nos valores limiares e na sazonalidade da temperatura e precipitação mensais do ar. A primeira versão dessa classificação foi desenvolvida no final do século XIX. Ainda é amplamente utilizada hoje em dia em várias aplicações e estudos condicionados a diferenças nos regimes climáticos, como modelos ecológicos e avaliações de impacto da mudança climática (Beck et al., 2018).

\section{Contribuição Nacionalmente Determinada (CND)} Termo usado pela UNFCCC quando um país aderente ao Acordo de Paris descreve seus planos para reduzir emissões. As CNDs de alguns países também descrevem como o país se adaptará aos impactos da mudança climática e os tipos de apoio de que precisa ou que poderá oferecer a outros países para que adotem caminhos de baixo carbono e aumentem sua resiliência climática. De acordo com o Artigo 4, parágrafo 2 do Acordo de Paris, cada Parte deverá 
elaborar, comunicar e manter as sucessivas CNDs que pretende alcançar. Antes da $21^{\text {a }}$ Conferência das Partes em Paris, em 2015, os países apresentaram suas Pretendidas Contribuições Nacionalmente Determinadas (PCNDs). Quando os países aderem ao Acordo de Paris, a menos que decidam o contrário, a PCND se transforma em sua primeira CND (IPCC, 2018a, p. 554).

\section{Convenção-Quadro das Nações Unidas sobre Mudança do Clima (UNFCCC) A UNFCCC foi} adotada em maio de 1992 e aberta à assinatura na Cúpula da Terra de 1992, no Rio de Janeiro. Entrou em vigor em março de 1994 e, em maio de 2018, tinha 197 Partes (196 Estados e a União Europeia). O objetivo final da Convenção é "estabilizar as concentrações de gases de efeito estufa na atmosfera em um nível que impeça uma interferência antropogênica perigosa no sistema climático". As disposições da Convenção são seguidas e implementadas por dois tratados: o Protocolo de Quioto e o Acordo de Paris (IPCC, 2018a, p. 559-560).

\section{Dióxido de carbono equivalente $\left(\mathrm{CO}_{2} \mathrm{eq}\right)$}

É a quantidade de emissão de dióxido de carbono $\left(\mathrm{CO}_{2}\right)$ que causaria a mesma força radiativa integrada ou mudança de temperatura, em um determinado horizonte de tempo, que a quantidade emitida de um GEE ou uma mistura de GEE. Existem várias maneiras de calcular essas emissões equivalentes e escolher horizontes de tempo apropriados. Geralmente, a emissão equivalente $\mathrm{a} \mathrm{CO}_{2}$ é obtida multiplicando a emissão de um GEE pelo seu potencial de aquecimento global (PAG) em um horizonte de 100 anos. Para uma mistura de GEE, somam-se as emissões equivalentes de $\mathrm{CO}_{2}$ de cada gás. $\mathrm{A}$ emissão equivalente a $\mathrm{CO}_{2}$ é uma escala comum para comparar as emissões de diferentes GEE, mas não implica a equivalência nas respostas à mudança climática. Geralmente, não há conexão entre emissões equivalentes a $\mathrm{CO}_{2}$ e concentrações resultantes equivalentes $\mathrm{a} \mathrm{CO}_{2}$ (IPCC, 2018a, p. 546).

Ecossistema É um complexo dinâmico de comunidades vegetais, animais e de microrganismos e seu ambiente não vivo que interagem como uma unidade funcional. Os ecossistemas podem ser pequenos e simples, como um lago isolado, ou grandes e complexos, como uma floresta tropical específica ou um recife de coral em mares tropicais (IUCN, 2011, p. 22).

Efeito estufa É o processo de aquecimento da terra por meio da absorção de radiação infravermelha pela atmosfera. Em linguagem comum, o termo "efeito estufa" pode ser usado em referência ao efeito estufa natural, causado pela ocorrência natural de GEE, ou em referência ao efeito estufa antropogênico, decorrente de gases emitidos por atividades humanas (IPCC, 2012, p. 560).

Exposição A presença de pessoas; meios de subsistência; espécies ou ecossistemas; funções, serviços e recursos ambientais; infraestrutura; ou bens econômicos, sociais ou culturais em locais e ambientes que possam ser afetados adversamente (IPCC, 2012, p. 559).

Forçamento antropogênico Todos os fatores humanos que causam mudança climática (Myrrhe et al., 2013).

Gás de efeito estufa (GEE) Os gases de efeito estufa são constituintes da atmosfera, tanto naturais quanto antropogênicos, que absorvem e emitem radiação em comprimentos de onda específicos dentro do espectro da radiação terrestre emitida pela superfície da Terra, pela própria atmosfera e pelas nuvens. Essa propriedade causa o efeito estufa. Os principais GEE na atmosfera terrestre são vapor de água $\left(\mathrm{H}_{2} \mathrm{O}\right)$, dióxido de carbono $\left(\mathrm{CO}_{2}\right)$, óxido nitroso $\left(\mathrm{N}_{2} \mathrm{O}\right)$, metano $\left(\mathrm{CH}_{4}\right)$ e ozônio $\left(\mathrm{O}_{3}\right)$. Além disso, existem vários GEE $100 \%$ antropogênicos produzidos na atmosfera, como os halocarbonos e outras substâncias que contêm cloro e bromo, cobertas pelo Protocolo de Montreal. Além de $\mathrm{CO}_{2}, \mathrm{~N}_{2} \mathrm{O}$ e $\mathrm{CH}_{4}$, o Protocolo de Quioto trata de hexafluoreto de enxofre $\left(\mathrm{SF}_{6}\right)$, hidrofluorocarbonetos (HFC) e perfluorocarbonetos (PFC) (IPCC, 2018a, p. 560). 
Mercado de carbono É um sistema de comércio no qual os países podem comprar ou vender unidades de emissão de GEE para atingir seus limites nacionais de reduções de emissão no âmbito do Protocolo de Quioto ou de outros acordos, como aquele em vigor entre os Estados membros da União Europeia. Esse termo foi escolhido porque o $\mathrm{CO}_{2}$ é o GEE predominante; outros gases são medidos em unidades denominadas "dióxido de carbono equivalente" (UNFCCC, n.d.).

\section{Mitigação (da mudança climática) É uma} intervenção humana para reduzir as emissões ou melhorar os sumidouros de GEE (IPCC, 2018a, p. 554).

Modelagem climática (modelo climático) É uma representação numérica do sistema climático com base nas propriedades físicas, químicas e biológicas de seus componentes, suas interações e processos de feedback, levando em conta algumas de suas propriedades conhecidas. O sistema climático pode ser representado por modelos de complexidade variável; ou seja, em relação a qualquer componente ou combinação de componentes, é possível identificar um espectro ou uma hierarquia de modelos, diferindo em aspectos como o número de dimensões espaciais, até que ponto os processos físicos, químicos ou biológicos são explicitamente representados ou o nível de envolvimento de parametrizações empíricas. Há uma evolução em direção a modelos mais complexos, com propriedades químicas e biológicas interativas. Os modelos climáticos são aplicados como ferramentas de pesquisa para estudar e simular o clima e para fins operacionais, incluindo previsões mensais, sazonais e interanuais do clima (IPCC, 2018a, p. 545).

Mudança climática Refere-se a uma mudança no estado do clima que pode ser identificada (por exemplo, com testes estatísticos) através de mudanças na média e/ou na variabilidade de suas propriedades e que persiste por um período prolongado, geralmente décadas (ou mais). A mudança climática pode decorrer de processos internos naturais ou forçamentos externos, como modulações dos ciclos solares, erupções vulcânicas e alterações antropogênicas persistentes na composição da atmosfera ou no uso da terra. $\mathrm{O}$ Artigo 1 da UNFCCC define a mudança climática como "uma modificação no clima atribuível, direta ou indiretamente, à atividade humana que altera a composição da atmosfera global e que, conjugada com as variações climáticas naturais, é observada durante períodos de tempo comparáveis". A UNFCCC faz, portanto, uma distinção entre a mudança climática atribuível a atividades humanas que alteram a composição atmosférica e a variabilidade climática, atribuível a causas naturais (IPCC, 2018a, p. 544).

\section{Potencial de aquecimento global (PAG) É a} potência relativa, molécula por molécula, de um GEE, levando em consideração quanto tempo ele permanece ativo na atmosfera. Os PAGs atualmente utilizados são os calculados em 100 anos. $\mathrm{O} \mathrm{CO}_{2}$ é considerado o gás de referência e recebe um PAG em 100 anos de 1. (Eurostat, n.d.)

Pagamento por serviços ambientais Abordagens baseadas no mercado que lançam mão de pagamentos ou recompensas para incentivar ou desincentivar práticas específicas de gestão de recursos naturais (IUCN, 2011, p. 54).

Restauração (de ecossistemas) É atingido quando se restabelecem todos os principais processos e funções ecológicos e toda a biodiversidade original (IPCC, 2018a, p. 548).

Sequestro de carbono É o processo de armazenamento de carbono em um sumidouro (UNFCCC, n.d.).

Serviços ambientais São funções ou processos ecológicos que têm valor monetário ou não monetário para certas pessoas ou para a sociedade em geral. Costumam ser classificados como: serviços de apoio, como produtividade ou manutenção da biodiversidade; serviços de provisionamento, como alimentos ou fibras; serviços de regulação, como 
regulação climática ou sequestro de carbono; e serviços culturais, como turismo ou apreciação espiritual e estética (IPCC, 2018a, p. 548).

Silvicultura É a arte e ciência de produzir e cuidar de florestas, manipulando seu estabelecimento, a composição de espécies, a estrutura e a dinâmica para cumprir objetivos de manejo (IUCN, 2011, p. 68).

Sistema climático É um sistema altamente complexo e composto por cinco componentes principais - atmosfera, hidrosfera, criosfera, litosfera e biosfera -, bem como as interações entre elas. $\mathrm{O}$ sistema climático evolui no tempo sob a influência de sua própria dinâmica interna e devido a forças externas, como erupções vulcânicas, variações solares e forçamentos antropogênicos, como a composição da atmosfera e a mudança do uso da terra (IPCC, 2018a, pp. 545-546).

\section{Soluções baseadas na Natureza São ações} para proteger, administrar de maneira sustentável e restaurar ecossistemas naturais ou modificados, que tratem dos desafios da sociedade de maneira efetiva e adaptativa, proporcionando, simultaneamente, o bem-estar humano e os benefícios da biodiversidade (IUCN, 2016).

Vulnerabilidade É a propensão ou predisposição a efeitos adversos. A vulnerabilidade abrange uma variedade de conceitos e elementos, incluindo a sensibilidade ou suscetibilidade a danos e a falta de capacidade de enfrentamento e adaptação (IPCC, 2018a, p. 560). 


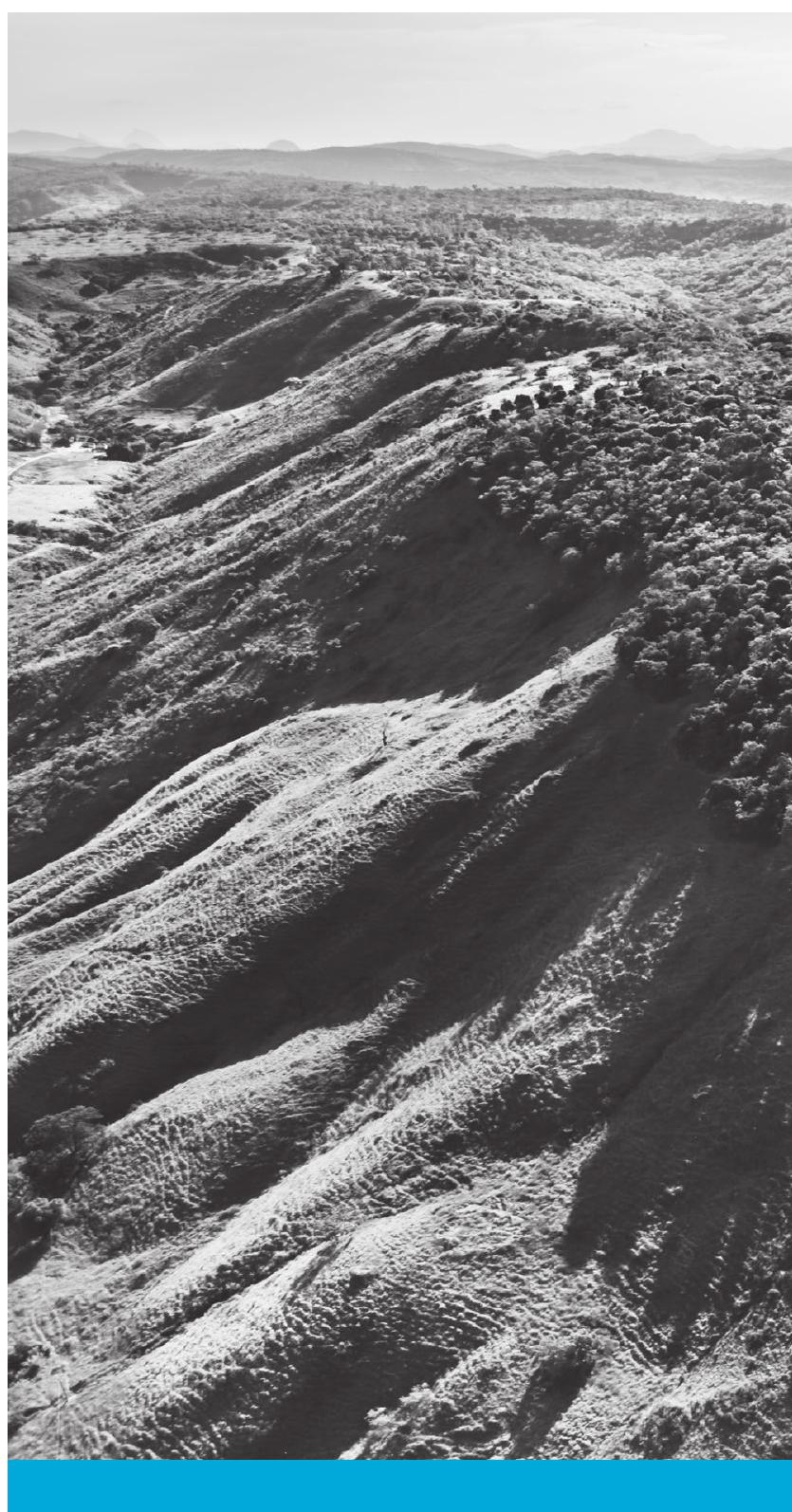

www.iucn.org 